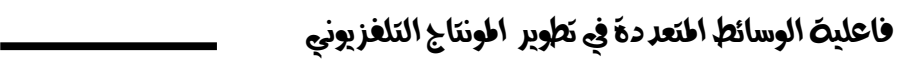

فاعلية الوسائط المتعددة في تطوير المونتاج التلفزيوني

(دراسة مقارنة على برنامجي أثشرقت والتفاح الأخضر بقناتي النيل

الأزرق و MBC1)

أ. زينب حاتم أحمد كرار

د. دأسامة حسب الرسول البشير"

\title{
The Effectiveness of Multimedia in the Development of Television Montage
}

(comparative study on ashragat and green apple programs on the blue nile and

mbc1 channels)

Dr.Osama Hassab EIrasoul Albashier Mr.Zeinab Hatim Ahmed Karrar

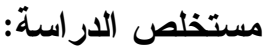

يناقش هذا البحث فاعلية الوسائط المتعددة في تطوير المونتاج التلفزيوني، ويهدف إلى معرفة متطلبات البرنامج التلفزيوني، و التعرف على المفاهيم الحديثة التي تتعلق بالوسائط المتعددة ومعرفة علاقتها بالعلوم الفيزيائية و الهندسية واستخدام تلك المفاهيم على البرامج التلفزيونية، بالإضافة إلى الفهم الجيد لمضمون المونتاج كجزء من عملية بناء البرامج التلفزيونية. أما مشكلة البحث فتكمن في جمود بعض البرامج التلفزيونية المحلية و افتقارها لبعض عناصر منر الجذب وعدم توفر دوافع المشاهدة لدى بعض المشاهدين، مقارنة بما يقابلها من برامج في لئه القنو ات الخارجية، ومعرفة أسباب ذللك الجمود، وتتمثل مشكلة البحث في السؤ ال الرئيس التالي: ما مدى فاعلية الوسائط المتعددة في تطوير المونتاج التلفزيوني؟ استخدم البحث المنهج المقارن، ولتوضيح الفرق بين نوظيف فاعلية الوسائط المتعددة في تطوير المونتاج بالتطبيق على برنامجي أثنرقت و التفاح الأخضر، و الأدوات التي استخدمت في البحث الملاحظة العلمية و المقابلة والاستبانة، لجمع البيانات اللازمة لتحقيق أهداف البحث، يتكون مجتمع البحث من

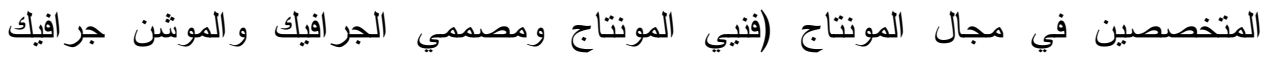
و المخرجين) لأنهم أكثر معرفة وقدرة على تحقيق منطلبات البحث من خلال الواقع العملي، ومن أهم النتائج التي توصل إليها البحث: أثنبث البحث أنّ الجر افيك الجيد بنوعيه ثنائي الأبعاد

* أستاذ مساعد بكلية علوم الاتصال - جامعة السودان للعلوم و التكنولوجيا.

"** محاضر بكلية علوم الاتصال - جامعة السودان للعلوم و التكنولوجيا.

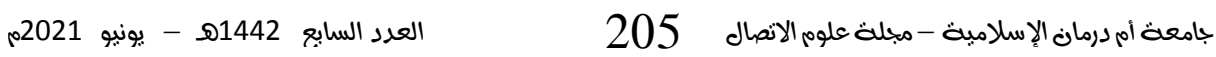




$$
\begin{aligned}
& \text { د. أسامة حسبع الرسول - أ. زينبَ حاتم أحمر كرار } \\
& \text { وثلاثي الأبعاد جاذب للمحتوى.أثبت البحث أن المونتاج العام للفيديو المتمثل في تكوين اللقطات } \\
& \text { وزو اياها وتكوين الصورة و ألو انها و الصوت و الموسيقى و الثخصيات يزيد من جودة الفيديو. } \\
& \text { أكد البحث تحقيق الانسجام بين عناصر الوسائط المتعددة التي تظهر في الثكل العام للصورة. } \\
& \text { و على ضوء هذه النتائج تم وضع عدد من التوصيات منها: التوظيف الجيد للصورة و استخدام }
\end{aligned}
$$

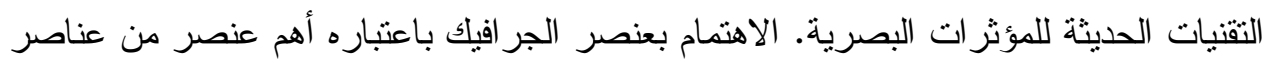

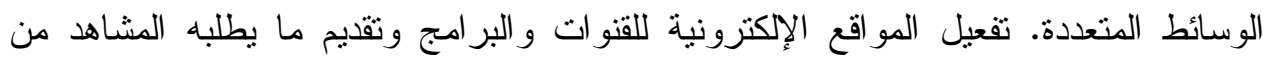

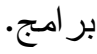

$$
\begin{aligned}
& \text { الكلمات المفتاحية : الجر افيك- الهولوجر ام- المونتاج الإكتروني - الو اقع الافتز اضي. }
\end{aligned}
$$

\section{Abstract:}

This research discusses the effectiveness of multimedia in the development of television montage, and aims to know the requirements of the television programs, to identify modern concepts related to multimedia and to know its relationship with the physical and engineering sciences and the use of these concepts on television programs, as well as a good understanding of montage content as part of television programs construction process. As for the research problem, it lies in the stagnation of some local TV programs and their lack of some elements of attraction and the lack of motivation for watching among some viewers, compared to the corresponding programs on foreign channels, and knowing the reasons for that stagnation. The research problem is represented in the following main question: What is the effectiveness of multimedia in the development of television montage? The research used the comparative approach, in view of clarifying the difference between employing the effectiveness of multimedia in developing montage for the two programs (Ashragat. Altufah Alakhdar). The tools used by the research are: scientific observation, interview and questionnaire form, to collect the necessary data to achieve the research objectives.

The research community consists of specialists in the field of montage (montage technicians, graphic and motion graphic designers, and directors) because they are more knowledgeable and able to fulfill research requirements through practical reality.

Among the most important findings of the research: Research has proven that the good graphics of their - two and three dimensions are attractive for content. Research has proven that general video montage consisting of composition of shots and their angles, composition of the 


\section{فاعلبة الوسائط المتعد دةً في تطوير الطونتاج التلفزيوني}

image and its colors, sound, music and characters increases the quality of the video. The research confirmed the achievement of harmony between the multimedia elements that appear in the general shape of the image. In the light of these results, a number of recommendations were made, including: Good use of the image and the use of modern techniques for visual effects. The graphic component should be taken care of as the most important component of multimedia. Activating the websites of the channels and programs and providing the viewer with the programs.

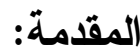

تعد الوسائط المتعددة من أهم عناصر التكنولوجيا و الإعلام الجديد، وتمنت بوابة لتحويل الموضوعات و الأفكار إلى الرسائل الإعلامية موجهة وقابلة للتأثثر سواء كانت مقروءة أو مسموعة أو مرئية أو مسموعة ومرئية، فالرســالة الإعلاميــة التي تشتمل على عناصر الوسائط المتعددة تجد حظها من التعرض و المشـــاهدة و التأثير ، وقد أدت الوسائط المتعددة دوراً حيوياً ومهماً في تكنولوجيا الاتصــال حيث أناحت سهولة الحصول على المعلومات وتبادلها وجعلها في متتاول طالبيها بسرعة وفاعلية، يركز البحث على فاعلية الوسائط المتعددة في تطوير المونتاج التلفزيوني، وذلك عن طريق الاستفادة من عناصر الوسائط المتعددة في التزاوج بين وسائل الإعلام و التكنولوجيا الحديثة.

مشكلة البحث: تتمنت مشكلة البحث في جمود بعض البر امج التلفزيونية المحلية في السودان و افتقار ها لبعض عناصر الجذب وعدم توفر دو افع المشاهدة لدى بعض المشاهدين، مقارنة بما يقابلها من برامج في القنوات الخارجية، ومعرفة أسباب ذلك الجمود، وتتمنل مشكلة البحث في السؤال الرئيس التالي: ما مدى فاعلية الوسائط المتعددة في تطوير المونتاج التلفزيوني ؟ أسئلة البحث:

1- ما المقصود بالوسائط المتعددة؟ 
2- إلى أي مدى يوجد فهم جيد لمضمون المونتاج كجزء من عملية صناعة البر امج

$$
\text { التلفزيونية ؟ }
$$

3- كيف يتسنى للوسائط المتعددة استخدام تقنياتها الحديثة في تطوير المونتاج

$$
\text { التلفزيوني ؟ }
$$

4- ما المعوقات و المشاكل التي تو اجه استخدام الوسائط المتعددة في عملية المونتاج

$$
\text { ألتلفزيوني ؟ }
$$

يهتم البحث بكيفية الاستفادة من توظيف الوسائط المتعددة في تطوير المونتاج التلفزيوني، وتقديم المونتاج بأنو اعه المختلفة بطريقة سهلة مع مر اعاة جودة المضمون في البرنامج التلفزيوني، علماً بأن البر امج التلفزيونية أصبحت ثقدم ما ينتظره الجمهور على حسب رغباتهم من خلال الاستفادة من عناصر الوسائط

$$
\text { أهداف البحث: يتعدة وتوظهها في المونتاج التلفزيوني. }
$$

1. التعرف على إمكانيات الوسائط المتعددة في تطوير المونتاج التلفزيوني. 2. تسليط الضوء على كيفية توظيف الوسائط المتعــددة فــي تطــــير المونتــاج

$$
\text { التلفزيوني. }
$$

3. استقر اء ومعرفة المشاكل و المعوقات التي تو اجه عملية المونتاج التلفزيوني. منهج البحث: حدد العلماء المنهج بأنه فن التظظيم الصحيح لسلسلة من الأفكـار العديدة، إما من أجل الكثف عن حقيقة مجهولة لدينا أو من أجل البرهنة علـى دنى حقيقة لا يعرفها الآخرون" (1). واستخدم في هذا البحث المنهج المقارن و المنهج الوصفي التحليلي للمقارنة بين برنامج أثرقت بقناة النيل الأزرق وبرنامج التفاح الأخضر بقناة MBC1 من حيث أوجه التشابه و الاختلاف في توظيف عناصــر الوسائط المتعددة المستخدمة في مر احل المونتاج التلفزيوني. 


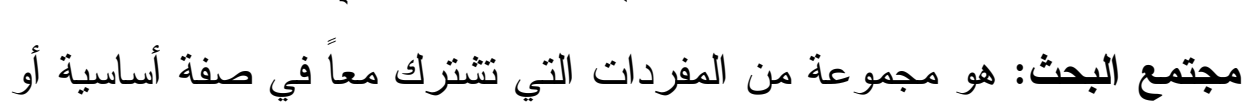

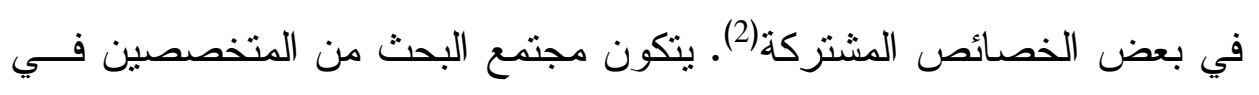

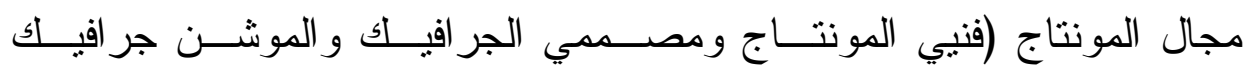

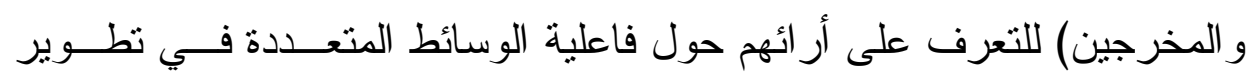

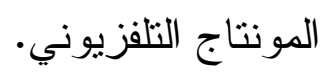

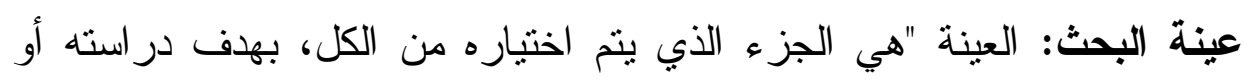

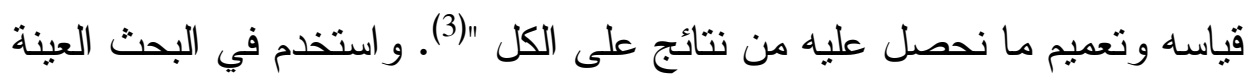

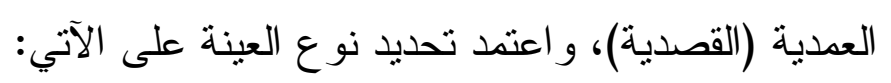

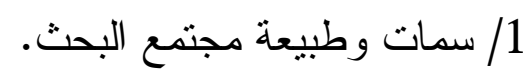
2/ منوع واسلوب البحث.

حدود البحث: حدد هذا البحث عدد من المحدات البشرية و الزمانية والمكانيــة

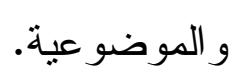
الحدود البشرية: اقتصر البحث على المتخصصين في مجال المونتاج التلفزيوني

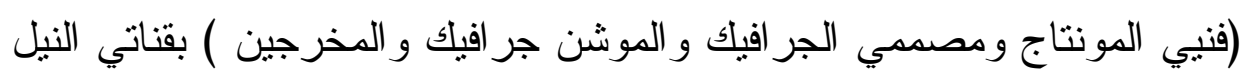

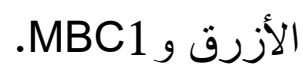
الحدود الزمانية: يغطي البحث الفنرة الزمانية من الأول من شهر يناير 2015م

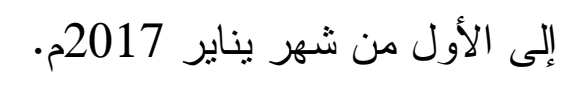
ويمكن تبرير الختيار هذه الفنرة للآني: 1- تنتل امتداد للار اسات الني أجريت في الفترة حتى 2015 2015.

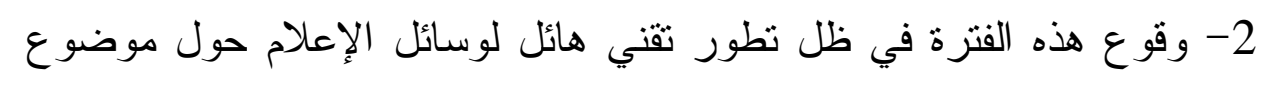
توظيف الوسائط المتعددة في تطوير المونتاج التلفزيوني.

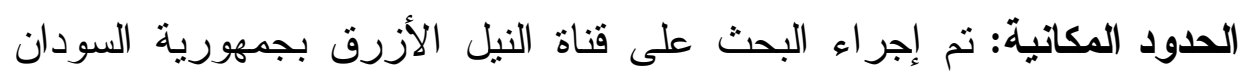

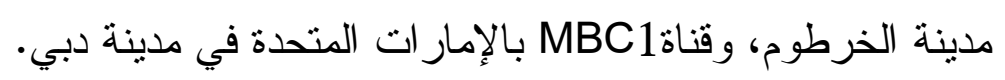




\section{د. أسامة حسب الرسول - أ. زينب حاتم أحر كرار}

الحدود الموضوعية: انحصر البحث على تتاول فاعلية الوسائط المتعددة في تطوير المونتاج التلفزيوني. المصطلحات والمفاهيم:

\section{الوسائط المتعددة :}

إصطلاحاً: الوسائط المتعددة مزيج من المواد الإعلامية التـي هــي الصــوت و الصورة و النص ولقطات الفيديو (4). إجر ائياً: هي الصوت و الصورة و الفيديو و النص و المؤثز ات الصوتية و البصرية المستخدمة في البر امج التلفزيونية التي تعتمد على المحتوى الوسائطي. تطوير: لغة: طوَر يطور، تطويرًا، فهو مطور ، و المفعول مطوَر، طور المصنع: عدله وحسنه ونقله من حال إلى حال (5). اصطلاحاً: رفع مستوى العاملين علمياً وفنياً (6). إجرائياً: هو الوصول بالثيء المطور أو النظام إلى أحسن صورة حتى يؤدى الغرض المطلوب منه بكفاءة نامة، ويحقق كل الأهداف المنشودة على أنت وجه.

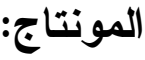
لغة: تصنيع الصورة المركبة عن طريق ضم عدد من الصور المســقلة إلـى بعضها البعض. (7) اصطلاحا: Editing بالإنجليزية -montage بالفرنسية، هو فن اختيار ونرنيب المشاهد وطولها الزمني على الثاشة بحيث تتحول إلى رسالة محددة المعنـي، بمعنى أنه أداة لتوصيل المشاهد إلى ردة فعل ونوع من الصدمة وهذا ما بترتب عليه هدف البرنامج التلفزيوني (8). إجرائياً: هو عملية الربط المتحكمة في توظيف معطيـات الوســائط المتعــددة و اختيار ها بالهدف المحدد و الغرض المعين لإكمال ما يسمى بالبرنامج. 
لغةً: جهاز نقل الأصوات و الصور بواسطة الأمو اج الكهربائية(9).

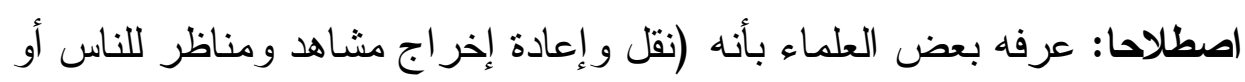

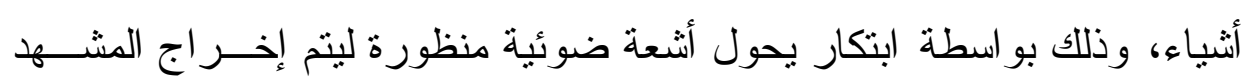
الأصلي في أماكن بعيدة(10). إجرائياً: هو الوسيط الإعلامي الذي يعرض البرنامج التلفزيــوني عبــر البـــث الأرضي أو القناة الفضائية أو الألياف الضوئية عن طريق الاستفادة من عناصر ومحتوى الوسائط المتعددة. الار اسات السابقة: الار اسة الأولى: فاعلية الوسائط المتعددة في إنتاج بــر امج التلفزيـــون در اســـة تطبيقية على التصميم الإيضاحي بتلفزيون السودان (11) من أهم أهداف الدراســة

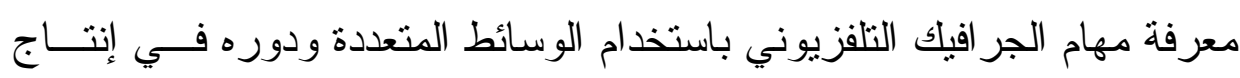

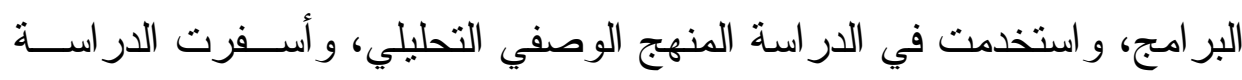
الخروج بمجمو عة من النتائج أهمها:

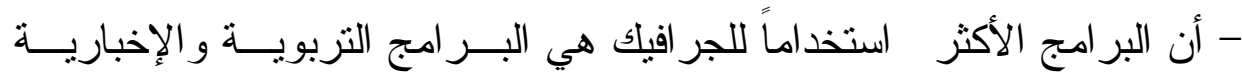
و السياسية في تلفزيون السودان. العلاقة و المقارنة بين الدراستين :

- ركزت الدراسة على فاعلية الوسائط المتعددة في إنتاج برامج التلفزيون من الناحية النظرية وانعكاس ذلك على الناحية العملية والوقوف على إيجابيات وسلبيات التطبيق، بينما ركزت الدراسة الحالية على فاعلية الوسائط المتعددة في التطوير و الارثقاء بالمونتاج التلفزيوني. 
د. أسامة حسب الرسول - أ. زينب حاتم أخد كرار

موقف الاراسة الحالية والإضافة المرجوة:

- على الرغم من أن هنالك بعض الاختلافات بين الدر استين إلا أنه يمكن القول

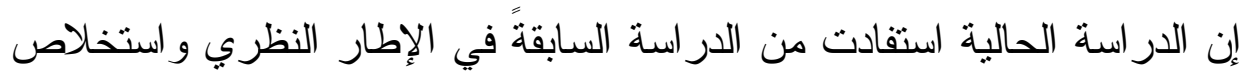

النتائج.

الاراسة الثثانة: فاعلية الصوت و الصورة في الصنتج التلفزيوني(12).

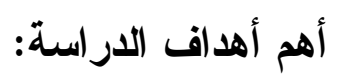

- الوقوف على تطور مدخلات ومخرجات صناعة الصورة و الصوت في الفنون السمعية و البصرية استخدمت الدراسة المنهج الوصفي النحليلي ومن أهم نتائجها:

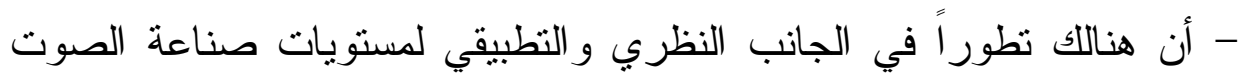
و الصورة في الفنون السمعية و البصرية بالسينما، و التلفزيون، و الوسائط المتعددة و الفيديو .

\section{العلاقة و المقارنة بين الاراستين:}

اهتمت الدر اسة بفاعلية الصورة و الصوت خاصة في عملية صـــاعتهما

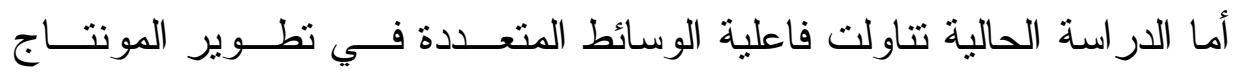

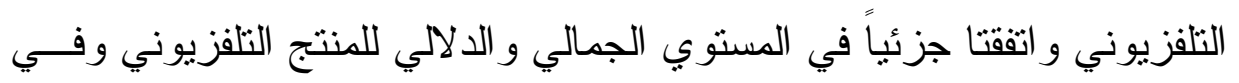
كيفية توظيف الصورة و الصوت.

\section{موقف الار اسة الحالية والإضافة المرجوة:}

استفادت الدراسة الحالية من الدراسة السابقة في قراءة ملامح تطور المونتاج، وفي صياغة بعض محاور الاستبانة ومن ثم تحاول الدر اسة استكمال ما لم يتم التطرق إليه في الدر ساعة السابقة. 


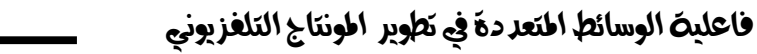

تعريف الوسائط المتعددة:

" مصطلح لوصف إتحاد البرامج والأجهزة التي تمكن المستخدم من الاستفادة من النصوص و الصور و الصوت و العروض و الصور المتحركة ومقاطع الفيديو"(13).

الوسائط المتعددة Multimedia هي "مجمو عة من تطبيقــات الحاســوب التـي يمكنها تخزين المعلومات بأثنكال متتوعة وجمالية، ومتقنــة بثـــكل احتر افــي،

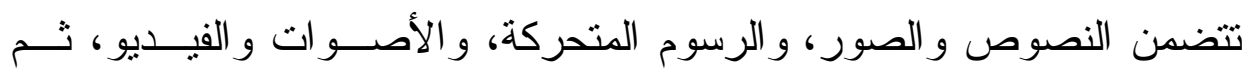
عرضها بطريقة تفاعلية وفقاً لمسار ات المستخدم"(14)

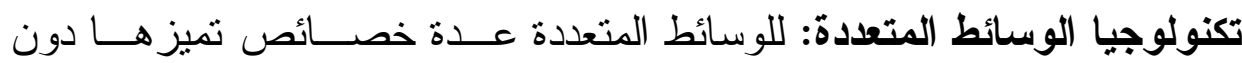
غير ها من المجالات العلمية و العملية الأخرى ونتشتق هــذه الخصـــائص مــن مجموعة من الأسس المرتبطة بنظريات التعليم و التعلم و الهندســـة و الاتصــال

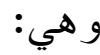
1- التفاعلية Interactivity: نوفر هذه البيئة الاتصالية ما يسمى بثنائية الاتجاه على الأقل حيث تمكن المستخدم من اختيار المعدل الذي يناسبه من التعلم أو المشاهد، ويمكن أن يختار العديد من الخيارات أو البدائل الأخرى ومن الأمتلة على الوسائط المتعددة التفاعلية، الفيديو التفاعلي، أنماط التعليم التفاعلية، نظم النصوص الفائقة و الوسائل المتعددة الفائقة(15). 2- التتوع Diversity: توفر تكنولوجيا الوسائط المتعددة بيئة متتوعة يجد كل مستخدم ومتعلم ما يناسبه وترتكز على إثارة القدرات الذهنية و المعرفية لدى المتلقي من خلال ما يسمعه ويشاهده(16). 3- الكونية Globalism: أصبح من السهل معرفة كلما يحيط بنا من أخبار ووقائع و أصبح العالم قرية صغيرة بمساعدة تكنولوجيا الوسائط المتعددة التي جعلت الانفتاح على العالم وثقافاته وتداول المعارف من خلال المواقع 
د. أسامة حسب الرسول - أ. زينبه حاتم أحر كرار

الإلكترونية و التلفزيون و غيرها من وسائل الاتصال الخاصة بالعملية التعليمية أمر اً متاحاً (17)

4- الفردية Individuality: توجد الفردية في المواقف التعليمية التي تقوم على مبدأ الخطو الذاتي Self Pacing ويتم تزويد المتعلمين بالتوجيه و القدرة على التعلم الذاتي الفردي لتحقيق الهدف المنشود(18). 5- التكاملية Integration: كلما كان هناك تكامل في عناصر الوسائط المتعددة الصوتية و الصورية والرسومية و النصية تكاملاً وظيفياً فإن تحقيق الهدف المنشود سهلاً (19).

وتتحقق التكاملية عندما ير اعي المصممون تصميم عناصر الوسائط المتعددة وكأنها تتكامل في إطار و احد وتتكامل في اتساقها ومحتو اها وترتيبها وحركتها لتحقيق الهدف المنشود في نظام و احد متكامل(20). 6- المرونة Flexibility: المرونة من الخصائص المميزة و المهمة في بر امج تكنولوجيا الوسائط المتعددة و إمكانية التحكم في عناصر الوسائط المتعددة سواء في عملية الإنتاج أو العرض(الونائ. 7- التزامنية Synchronization: تعني عرض عناصر الوسائط المتعددة وفق أدوارها ومتطلباتها المتداخلةً مع بعضها البعض بشكل منكامل وفي

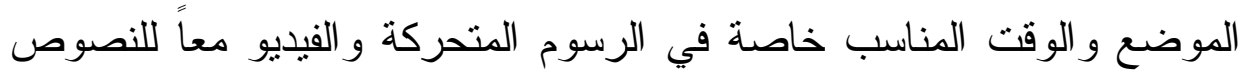
و الصور (22). 8 -الإكترونية Electronic: هي الخاصية الأساسية لبناء مشروع وتطبيق و عرض تكنولوجيا الوسائط المتعددة لأنها تتتج وتصمم وتعرض على الأجهزة الرقمية الإلكترونية وأن العصر الحالي هو العصر الرقمي ويوجد تحول كبير في الأدوات في مختلف المجالات حتى أن السبورة أصبحت سبورة تعليمية ذكية في (23). 


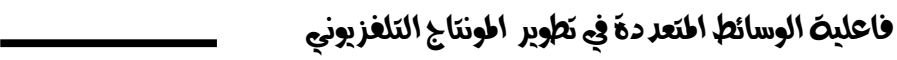

9 -التبادلية Interchangability: تتيح الوسائط المتعددة للطلاب اختيار المسار الذي يناسبهم ويرغبون في مشاهدته وذلك لكي نعطي الطلاب الحق في التحكم في المعلومات الني تظهر على الثانشة وزمن ظهور هـا(24). 10سرعة الأداء Fast Performance: تعد برامج الوسائط المتعددة من أقوى و أسر ع البر امج في استدعاء المعلومات وتحليلها. عناصر الوسائط المتعددة :

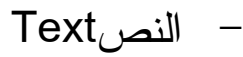
Images الصور الثابتة - الصور المتحركة Animation ومن أهم إمكانيات تكنولوجيا الوسائط المتعددة(25):

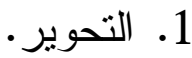

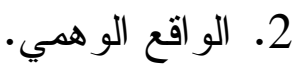

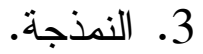

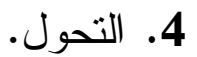

الإنفوجر افيك Infographic تعريفه: هو تمثيل مرئي لأي نوع من المعلومات أو البيانات.

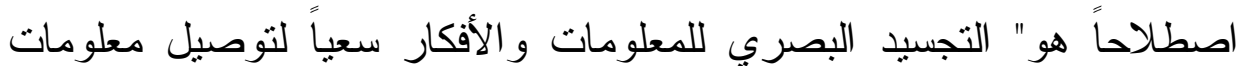
معقدة لجمهور ما بطريقة تمكنهم من فهمها واستيعابها بسرعة" يمزج الإنفوجر افيلك بين التصميمات و البيانات أو المعلومات المساعدة، ونجد أن هنالك مسميات أخرى تطلق على عملية إنشاء الإنفوجر افيك منل التجسيد البصري 
د. أسامة حسب الرسول - أ. زينبه حاتم أحم كرار

Information لبيانات Data Visualization أو العمارة المعلوماتية (26)information Design أو تصميم المعلومات Architecture يمر النموذج الإنفوجر افيكي بخمس مراحل وهي (27): 1.مرحلة الدراسة والتحليل: وما يحدث في هذه المرحلة هو تحليل المادة المر اد تصميمها حسب نو عيتها. 2.مرحلة التخطيط: يتم فيها تصميم المخطط لعناصر الإنفوجر افيك وصياغة المحتوى وتمثنيله. 3.مرحلة التصميم: يتم تجميع العناصر البصرية باستخدام أحد بر امج تصميم الجر افيك و عمل مر اجعة فنية وتمثيله بصرياً. 4.مرحلة التقويم: يتم التحكيم من قبل خبر اء بتقويم ددى اكتمال الإنفوجر افيك وصحته.

5.النشر والاستخدام: يتم في هذه المرحلة النشر للتصميم الإنفوجر افيكي على أثنكال الوسائط سو اء كانت في كتب أو مجلات أو مطبقات أو على التلفزيون أو أو

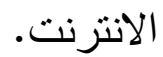

الأشياء التي تناعد الإنفوجر افيك في تحقيقها تجارياً على ضوء فلسفة نيجل هولمز هي (28): صياغة فلسفة و إستر اتيجية للمستثمرين. أ- إبر از المنتج ومميز اته وفو ائده للعملاء. ج- فرص الخدمات و الأعمال التي تفيد العملاء. د- طرح أفكار ووضع سياسات للعاملين لدى الثركة. الهولوجرام (التصوير التجسيمي): الهلوجرام هو عبارة عن صورة افتر اضية ثلاثية الأبعاد مطابقة للجسم المر اد ثمثيله باستخدام شعاعين من الليزر داخل وسط معين (29). 


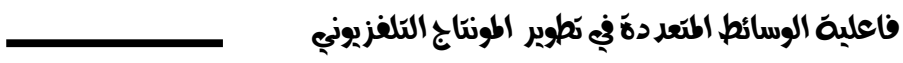

يتم التصوير المجسم أو الحصول على الهولوجرام على مرحلتين(30): • المرحلة الأولي: يسجل فيها أنماط التداخل ثم الحصول على الهولوجرام بإلتقاء أثنعة المرجع وأثنعة الجسم على اللوح الفوتوجر افي ويظهر نمط تداخل مناطق مظلمة داكنة و أخرى مضيئة شفافة.

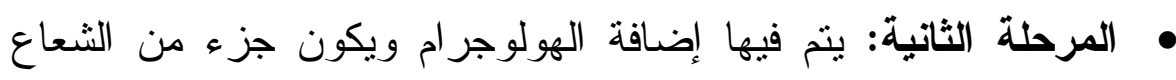
النافذ من الهولوجر ام مطابقاً لموجة الجسم الأصل ويتم إضـاءة الهولوجرام بأثنعة بيضاء وهي جزء من أثنعة المرجع.

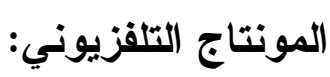
تعريف المونتاج: Editing بالإنجليزية -montage بالفرنسية، هو فن اختيار وترتيب المشاهد وطولها الزمني على الثاشة بحيث تتحول إلى رسالة محددة المعني، بمعنى أنه أداة لتوصيل المشاهد إلى ردة فعل ونوع من الصدمة وهذا ما يتزتب عليه هدف البرنامج التلفزيوني (31). تعني عملية المونتاج Montage أو التوليف Editing وضع اللقطات و الصور و الأصوات في وضع منآلف ومتتاسق وذلك باستخدام الحذف أو الإضافة أو إعادة الترنتب وفقاً لنو عية البرنامج ولتحقيق معنى وتأثير محدد.

المونتاج الإكتروني:Electronic montage:

المونتاج الإلكنروني شائع الاستخدام خاصة في الإذاعات و المحطات التلفزيونية لسهولته ودقته ومزاياه في توفير الوقت و الجهد يحتاج المونتاج الإككتروني إلى وحدتي الصوت و الصورة خاصة في مونتاج الفيديو ونتتوع أساليب مونتاج الفيديو على النحو التالي: أ. المونتاج المباشر: ويتم عند بث البرنامج التلفزيوني على الهو اء مباشرة من داخل الإستديو التلفزيوني أو الإذاعي أو من و اقع الحدث عن طريق أســتوديو 
د. أسامة حسب الرسول - أ. زينبه حاتم أحد كرار

مصغر مكون من غرفة مر اقبة وكامير او أجهزة صــونية بواســـة المخــرج

و المهندس وتتقل الصورة على الثبكة المتصلة بالأقمار الاصطناعية(32).

ب. مونتاج شريط الفيديو: يتم استخدام وحدة مونتاج مخصصة لهذا الغــرض

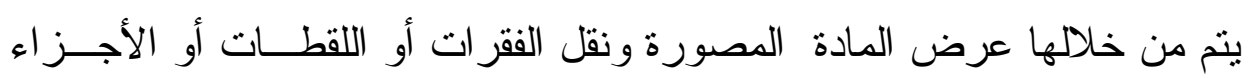

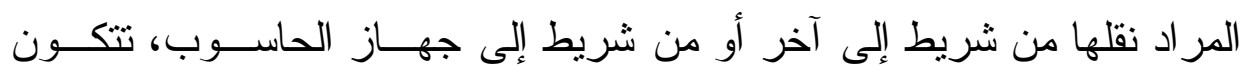

الوحدة من جهازين الأول للعرض و الثاني للتسجيل، هناللك جهاز آخــر بيـــى

المؤلف الإلكتروني Electronic Editor)

"هناللك ثلاثة نماذج للمونتاج تعين الجمهور على تفسير العلاقــة التــي تــربط اللقطات وفهمها(34):

Continuity Cutting توليف الربط -

في هذا النوع يستخدم القطع كنوع من الانتقال بين اللقطات بشكل متو اصل وهو أسهل أنو اع الأساليب في البر امج التلفزيونية. - توليف الصلة أو العلاقة Relation Cutting:

يكون القطع هنا لإظهار العلاقة الضمنية بين اللقطات التي لا تكون بينها صــلة مباشرة.

- التوليف المتحرك أو المتغير Dynamic Cutting: هو التوليف الذي يستخدم لإظهار العلاقة و الربط لتأكيد المعنى در امياً عن طريق المتغير أو المتحرك.

\section{طرق المونتاج ونماذجه Types of Editing:}

اقتبس المونتاج أهم قو اعده من صناعة الأفلام السينمائية خاصـــة فــي

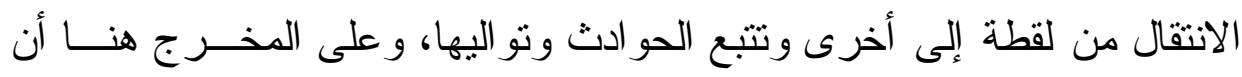

يتأكد أن المشاهد يفهم هذه المعاني ويفسر ها من الناحية الذهنية فيبــدأ بتفســير الصورة الجديدة على أساس: (أين نحنا لآن؟ما الذي يحدث؟ مأهن هذا؟؟). 


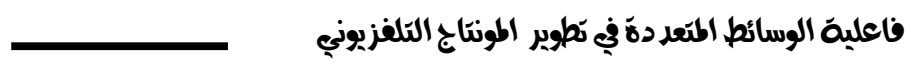

أساليب وسائل الاتثقال بين اللقطات تتمثل في الأتي: أ.القطع cut: هو من أكثر الأساليب بساطةً في الانتقال وهو الوسيلة العاديـــة

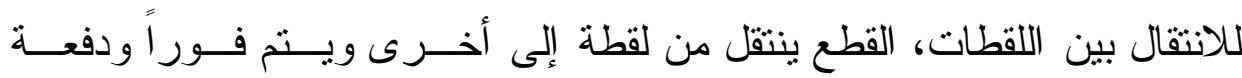
و احدة:(35).

$$
\text { ويستخدم لـــــــ }
$$

التأكيد- إظهار التتاقض و المقارنة بين شيائين- إظهــار التشــابه بــين

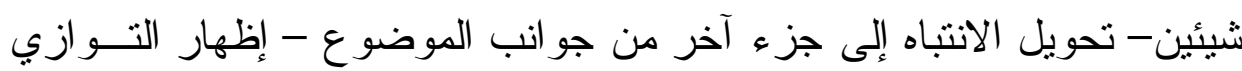
بين حادث و آخر - موقع الثيء بالنسبة لما يحيط به من مرئيات. ب. المزج Dissolve or Mixing: هو الانتقال التدريجي من لقطة إلى لقطة

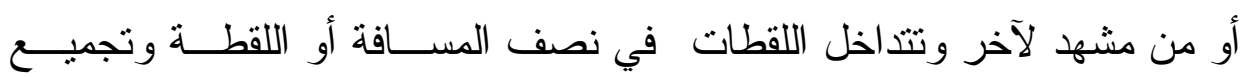
الصورنين في صورة واحدة من مصدرين مختلفين، مهام المزج هي (36):

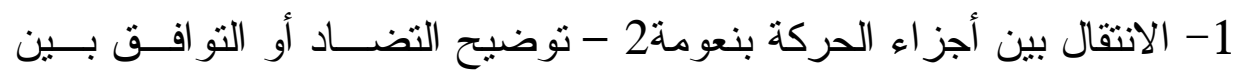

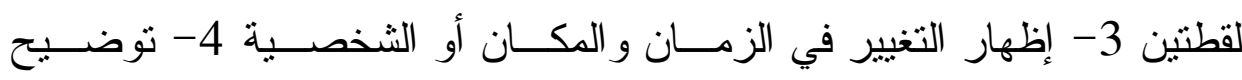
المشاعر الداخلية للمشاركين في العمل التلفزيوني.

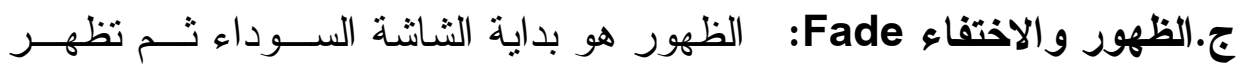
الصورة تدريجياً حتى تصل إلى أقصى وضوح لهاءول ويستخدم هذا الانتقال بمثابة

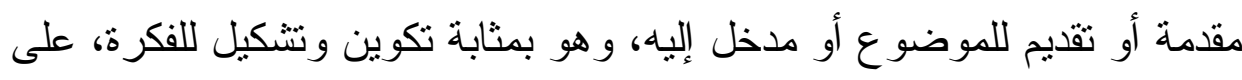

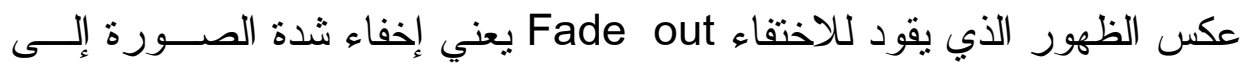

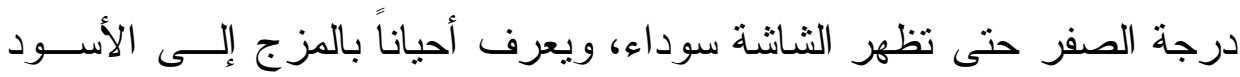
.${ }^{(37)}$ Fade to black

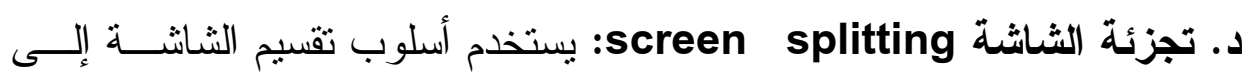

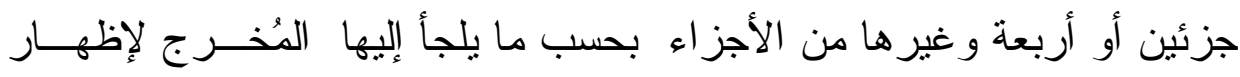


د. أسامة حسب الرسول - أ. زينبه حاتم أحد كرار

العلاقة بين الأشخاص أو الأماكن أو المناظر أو حدث في بلدين مختلفين لإظهار جو انب مختلفة بغرض أن تكمل بعضها بعضاً في المعنى و الغرض. ه.أسلوب الشاشة الزرقاء Chroma key - Shooting the blue: يستخدم أسلوب الثاشة الزرقاء أو المفتاح اللوني لمزج عدة لقطات وجمعها في مكان و احد وفي آن و احد(38).

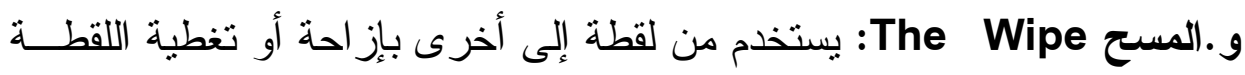

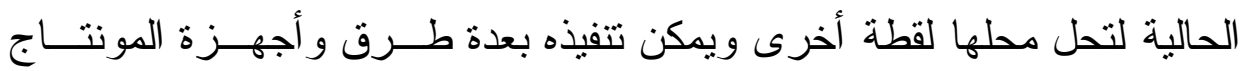
الإلكتروني مزودة بأساليب عدة(39).

ز · وصل اللقطات باستخدام عدم التركيز البؤري لها Out of focus: يشبه هذا الانتقال المزج ويستخدم في معظم الأحيان لنفس المهام التي يقوم بها، وتصبح نتيجة الصورة غير واضحة أو مطموسة وتظهر صورة جديدة

$$
\text { و اضحة (40). }
$$

د.التر اكب Superimposition:

هو ظهور تدريجي لصورتين من مصدرين يتز امن ظهور هما في وقت و احد ونشغلان الثاشة بكاملها، في المونتاج الخطي عن طريق المســح ويــتم بو اسطة يد أو زر اع المزج. يستخدم التر اكب للتعبير عن العديد من الأفكار ونقلها: الإشارة إلى أن هناللك حدثان بحدثان في نفس الوقت وفي أماكن مختلفة -توضيح التطور أو التقدم الذي يطر أ على الأشياء- إظهار الصورة الذهنية التي تدور في ذهن الشخص - للمقارنة و إظهار أوجه الثبه و الاخــتلاف بــين عــدة موضوعات - إظهار العلاقة بين الموضوع و أجز ائه(41). 


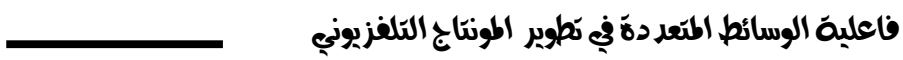

الحاجة إلى الأساليب الفنية:

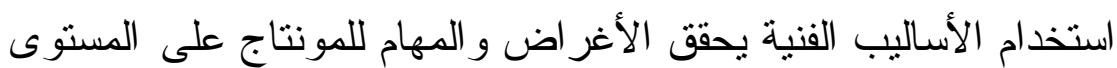

$$
\begin{aligned}
& \text { الفني الإبداعي و على المستوى الآلي الحرفي كما يأتي (42): } \\
& \text { أولاًا : فــنانياً: }
\end{aligned}
$$

التغلب على القيود و المشاكل الناجمة عن طبيعة التلفزيون كوسيلة و الثاشة المسطحة ذات البعدين التي تفتقر إلى البعد الثالث وبالتالي تكون

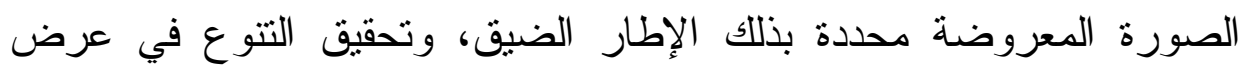
المناظر في أحجام وأثنكال متعددة، وخلق الانفعالات و الانطباعات، و وإضفاء

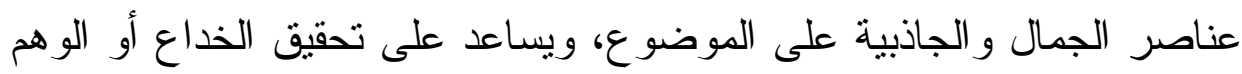
و التعبير عن الوقت و الحركة وتحقيق المؤثزات الخيالية. ثانياً: ميكانيكياً أو ألياً:

التغلب على قيود ومشاكل الآلات أو نقصها ومشاكل الاستمر ار الزمني

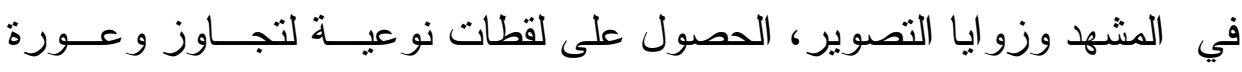

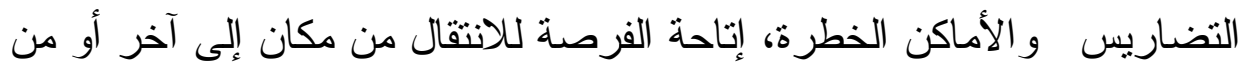

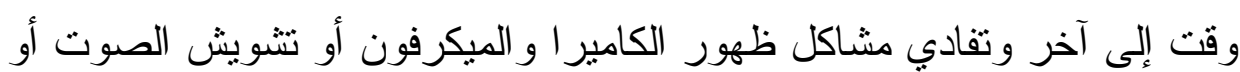

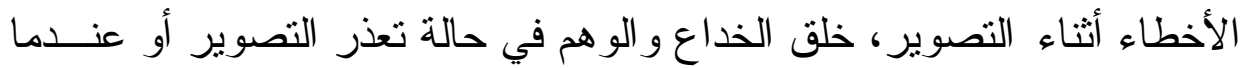

$$
\text { يكلف التصوير جهذاً كبيرًاً. }
$$

الوسائط المتعددة وتطور المونتاج التلفزيوني:

ساهم النطور التقني الذي صاحب الوسائط المتعددة فـــي تطــــور المونتـــاج

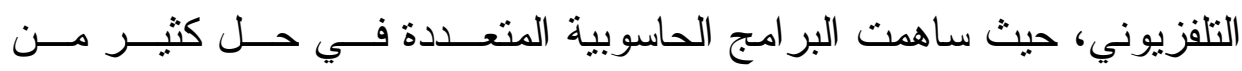

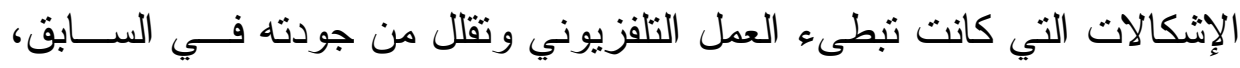

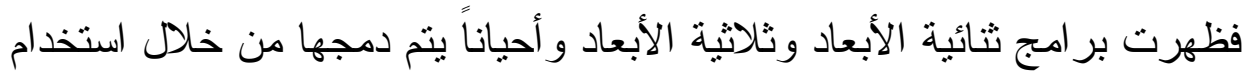


د. أسامة حسب الرسول - أ. زينبه حاتم أحر كرار

تقنية الوسائط المتعددة الحديثة والاستفادة من التجديــدات و التحســينات التـي تحتويها في إنتاج بر امج تلفزيونية عالية الجودة. الار اسة الميدانية:

\section{أولاً : نبذة تعريفية عن قناة النيل الأزرق:}

نشــــأت قناة النيل الأزرق كثر اكة بين الهيئة السودانية للإذاعة و التلفزيون ور اديو وتلفزيون العرب ART في أغسطس 2003م، حيث كانت تبثث إرسالها لمدة ساعتين في اليوم فقط في إطار باقة قنوات ر اديو وتلفزيون العرب (الأو ائل) وبنظام التشفير وفي 2010م أصبحت القناة تبث بنظام الدورة الكاملة على مدار 24 ساعة، وظلت الق ــناة تعتمد على مو اردها الخاصة من خلال التسويق و الإعلان و الرعايات لبر امجها المختلفة لمواجهة الكلفــــة العاليـــــــة لمدخــات العمل الإنتاجي التلفزيوني، حيث يتم ذلك وفق رؤية متوازنة بين المحتوى والتســــويق، فكانت تبثث برامجها على الترددات التالية على نايل سات 3000 V 12688 3000 و على عرب سات 10810 و 1000 رؤية ورسالة قناة النيل الأزرق كمؤسسة إعلامية تحاول إبراز الهويـــة و الثقافة السودانية عبر قو الب إبداعية تقدم بطر ح جديد، ساعية من خلص ذلـــك لوضع الثقافة السودانية في سباق مع الحداثة و الحضارة و الريادة، ولتشكل ملامح

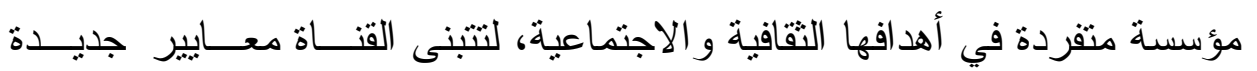
للتمبز، قو امها الكفاءة في العمل الإعلامي، القائم على التـــوازن بــين الثـــل

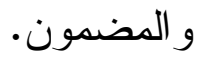

تهدف القناة إلى رسم صورة مشرقة تزّين هامة العمل الإعلامي الهادف لإبر از

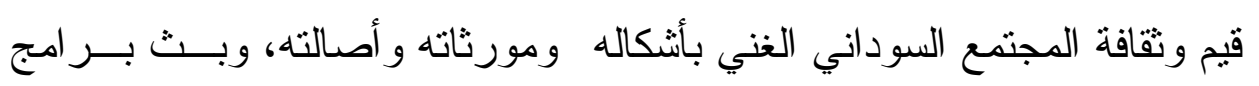
ثقافية تعطي ملامح للتقافة السودانية(43). 
فاعلبة الوسائط المتعد دة في نَطوير الطونتاج التلفزيوني

\section{نبذة تعريفية عن قتاة MBC1: - ن}

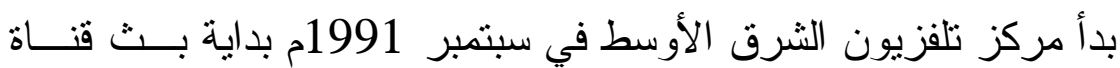

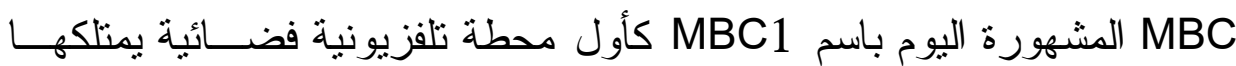
القطاع الخاص، تبث على مدار الساعة، وقد كان مقرها يقـــع بمدينــة لنــدن،

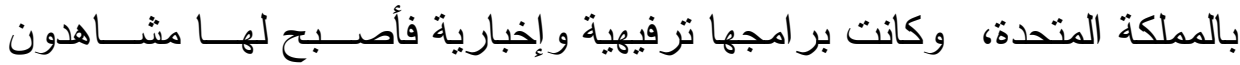
كثيرون في جميع أرجاء الوطن العربي، بعدها انتقلت إلى مدينة دبي الإعلامية

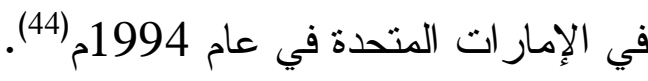
تردد قنو ات mbc1 نايلسات (45) $5 / 627500 \mathrm{~V} 11270$ تسعى قناة MBC1 من خلال رؤيتها ورسالتها إثر اء مسيرة حافلة مسن البث التلفزيوني المستقل ينظر بها العرب إلى العالم لارتباطها الوثيـق بالعــالم العربي، وهي مجموعة إعلامية تثري حياة الناس من خلال تزويدهم بالمعلومات

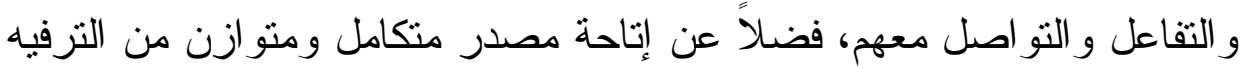
حيث تثمل المجموعة 12 قناة. (2018،MBC Group) تهذف القناة في ظل الطفرة التكنولوجية التي يشهدها العالم اليوم إلـى توســيع رقعة البث واستقطاب جمهور عالمي أكبر ، وتـــوفير محتــوى نـــوعي يمتـــاز بأخلاقيات رفيعة وجودة لا مثيل لها وفق رؤية طئة طموحة (46).

\section{برنامج أثرقت بقتاة النيل الأزرق:}

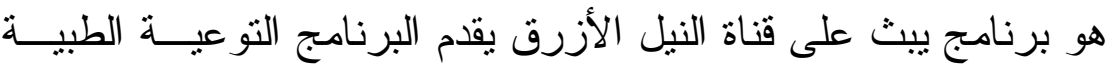

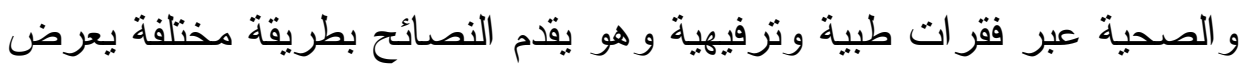

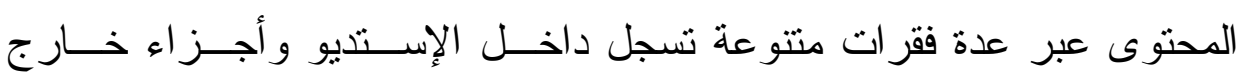

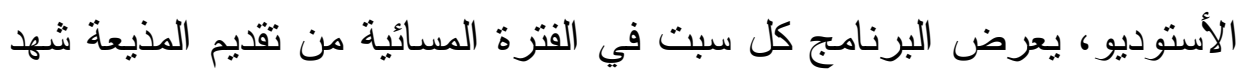

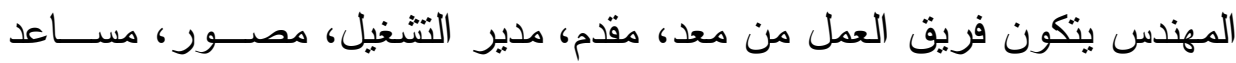


إنتاج، مهندسو تشغيل، مهندس إضـاءة، مصمم أزياء، مصمم جر افيك، مصــمم

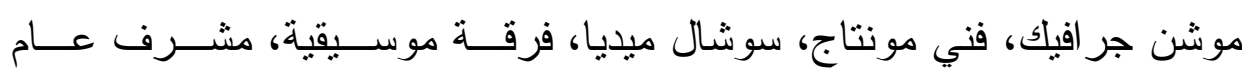

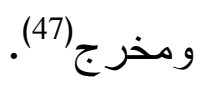

\section{برنامج التفاح الأخضر بقناة MBC1:}

هو برنامج يبث على قناة MBC1 كل جمعة في الفترة المســائية مــن تقديم هويدا أبو هيف يقدم البرنامج النصائح الطبية و الصحية و البيئيـــة ويقــدم فقر ات للرياضة و الجمال و التغذية يهتم البرنامج بالجمهور وحصوله على حيــاة صحية وتعزيز علاقة الفرد بالمجتمع ويثـارك الجمهور طر ح مثـــاكله عبــر

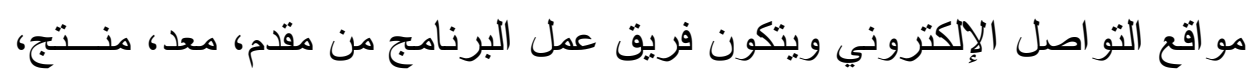
مشرف طبي، مساعد منتج، منتج فقر ات، أبحاث، منسق إنتاج، خدمات إنتاجية، منسق حجوز ات، مصور ، مسـاعد تصوير فني إضـاءة، مسـدير قســم الصــوت، مصمح صوت، مكياج، مصفف شعر ، مصمح جر افيك، تقني معلومــات، مسـدير العلاقات العامة و الثؤون التجارية، مدير علاقات الإنتاج، فني مونتاج، مــدير

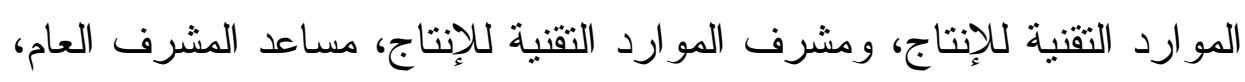

$$
\text { المشرف العام (48). }
$$

ثاتياً: الإجر اعات المنهجية للبحث:

يتتاول هذا المبحث منهج الدراسة، ويحدد مجتمعها وكيفية اختيار العينة وأهم خصائصها، ثم يستعرض أداة الدراسة ويتعرف على بنائها وصدقها وثباتها، و أخيراً كيفية تطبيق الار اسة المسحية والأساليب الإحصائية المستخدمة في تحليل بيانات الدر اسة.

منهج البحث: استخدام في البحث المنهج المقارن و المنهج الوصــفي التحليلـي للمقارنة بين فاعلية الوسائط المتعددة وتوظيفها في برنامج أثـــرقت وبرنــامج

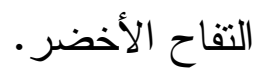




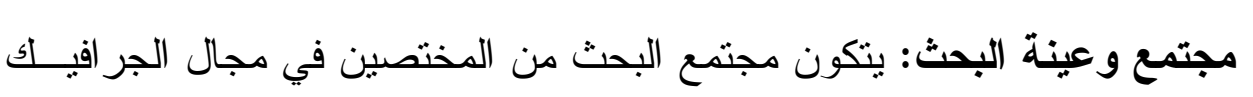

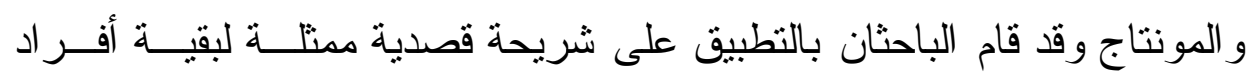

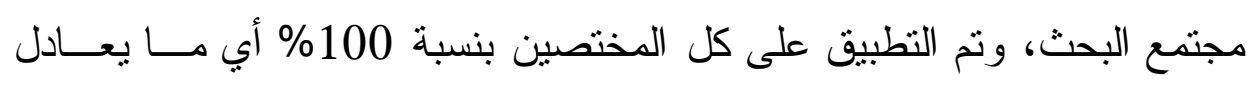

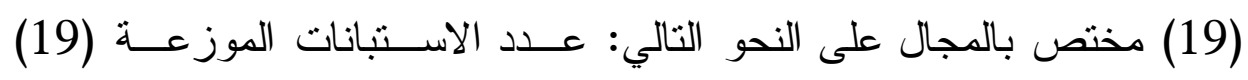

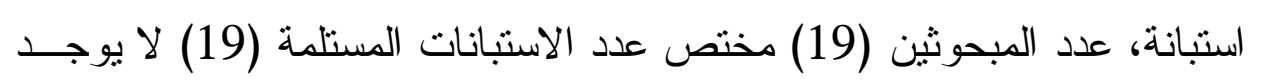
تالف من الاستبانات.

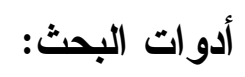

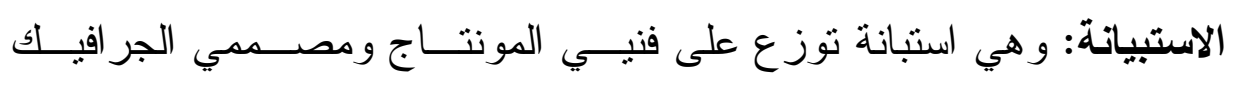

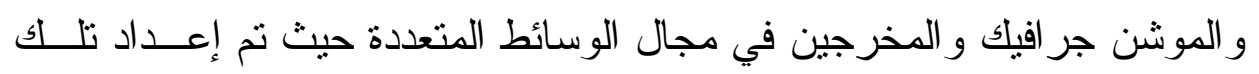
الاستبانة من قبل الباحثين، كذلك تم استخدام أداة الملاحظة العلميــة و المقابلــــة كأدو ات منهجية لهذا البحث. وصف الأداة: تكونت هذه الاستبانة من جزئين الجزء الأول البيانات الثخصــية و الجزء الثاني البيانات الموضو عية ويحتوي كل جزء على على عدد من الأسئلة.

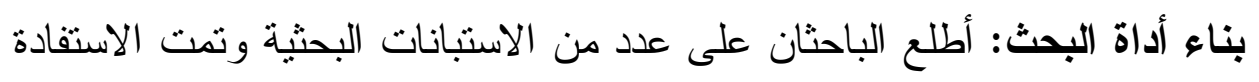

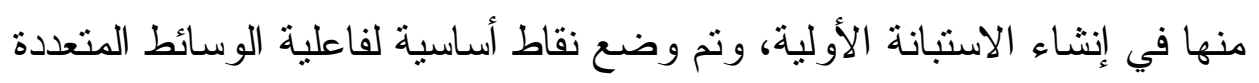
في تطوير المونتاج التلفزيوني. صدق أداة البحث: صدق الاستبانة يعني التأكد من أنها سوف تقبس ما أعدت

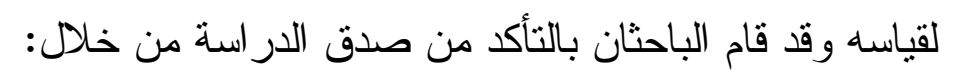

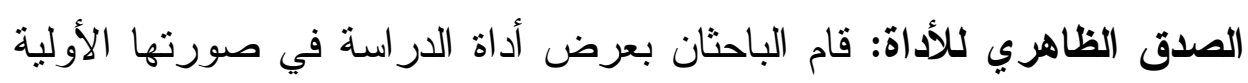

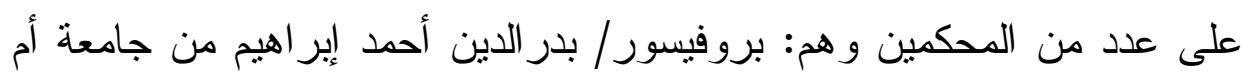

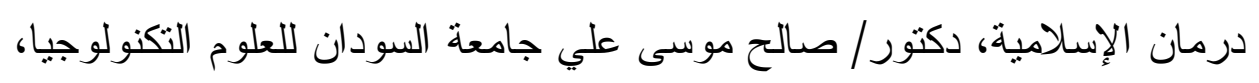

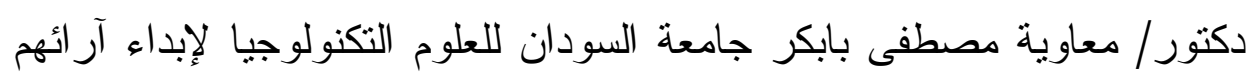


د. أسامة حسب الرسول - أ. زينبه حاتم أحد كرار

حول ملائمة العبار ات ومدى وضوح صياغتها لقياس ما وضعت لأجله، حيث تم

تعديل صياغة بعض العبار ات وحذف بعضها. الصدق البنائي (الاتساق الاخلي) لأداة البحث:

بعد التأكد من الصدق الظاهري لأداة البحث قام الباحثان بتطبيقها على عينة

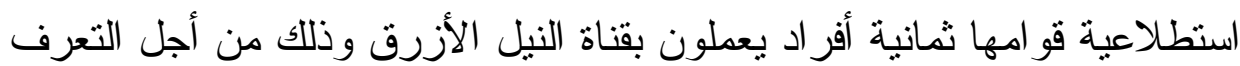
على مدى الاتساق الداخلي لأداة البحث.

الثبات والصدق الإحصائي: لحساب الصدق و الثبات الإحصائي لاستمارة الاسنبانة تم حساب ثبات وصدق الاستبانة من جميع المحاور بموجب معادلة ألفا كرونباخ والتي اتضح أنها تساوي 983.0 وهو أكبر من 0.7 مما يعطي مؤشر جيد لقوة وصدق الاستبانة وفهم عبار اتها من قبل المبحوثين.

الأساليب الإحصائية المستخدمة:

ولتحقيق أهداف الدراسة والتحقق من فرضياتها تم استخدام البرنامج الإحصائي(SPSS) و الذي يثير اختصاراً إلى الحزم الإحصائية للعلوم الاجتماعية، كما تم الاستعانة ببرنامج الإكسل (Excel) لتتفيذ اختبار المحاور المطلوبة في الدراسة وذللك عن طريق استخدام نتائج الأساليب الإحصائية

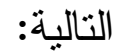

$$
\begin{aligned}
& \text { - التكر ار ات و النسب المئوية. } \\
& \text { - - الرسومات البيانية و النسب المئوية. } \\
& \text { - - مقياس ألفا كرونباخ لحساب معامل الثبات و الصدق الإحصائي. }
\end{aligned}
$$

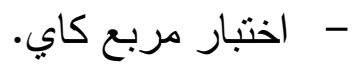




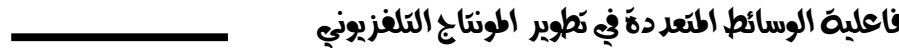

\section{عرض وتحليل وتفسير بيانات الاراسة الميدانية:}

يحتوى هذا المبحث على عرض وتحليل وتفسير بيانات ومعلومات الدر اسة الميدانية، ويضم آراء واتجاهات المتخصصين في المونتاج التلفزيوني ويمكن عرض نلاك الآر اء و الاتجاهات وتفسير ها على النحو التالي: جدول رقم (1) يوضح جاذبية ألوان الجر افيك و الصور (برنامج أثرقت)

\begin{tabular}{|c|c|c|}
\hline النسبة المئوية & التكرار & الفئة \\
\hline$\% 10.5$ & 2 & متتاز \\
\hline$\% 26.3$ & 5 & جيد جداً \\
\hline$\% 47.4$ & 9 & جيد \\
\hline$\% 10.5$ & 2 & وسط \\
\hline$\% 5.3$ & 1 & ضعيف \\
\hline$\% 100$ & 19 & المجهوع \\
\hline
\end{tabular}

شكل رقم (1) يوضح جاذبية ألو ان الجر افيك و الصور (برنامج أثنرقت)

$50.00 \%$

$45.00 \%$

$40.00 \%$

$35.00 \%$

$30.00 \%$

$25.00 \%$

$20.00 \%$

$15.00 \%$

$10.00 \%$

$5.00 \%$

$0.00 \%$

\begin{tabular}{|c|c|c|}
\hline & جيد جدأ & جن \\
\hline
\end{tabular}

\section{$47.40 \%$}

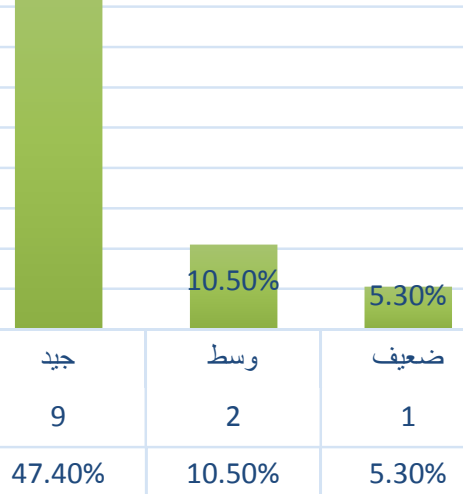

يلاحظ من الجدول و الثكل أعلاه أن جاذبية ألوان الجر افيك و الصور جيدة بنسبة بلغت 47.4\% من العينة المبحوثة بينما يرى 5.3\% من المبحوثين أن جاذبية الألوان للجرافيك والصور ضعيفة، يثير ذلك إلى أن ألوان الجر افيك 
د. أساهة حسبع الرسول - أ. زينبه حاتم أحمد كرار

المستخدمة في برنامج أثرقت جاذبة لبعض المشاهدين وتحتاج إلى مزيد من

الاهتمام.

جدول رقم (2) يوضح جاذبية الجر افيك لمحتوى البرنامج (برنامج أثرقت)

\begin{tabular}{|c|c|c|}
\hline النسبة المئوية & التكرار & الفئة \\
\hline$\% 15.8$ & 3 & ممتاز \\
\hline$\% 31.6$ & 6 & جيد جلاً \\
\hline$\% 15.8$ & 3 & جيد \\
\hline$\% 21$ & 4 & وسط \\
\hline$\% 15.8$ & 3 & ضعيف \\
\hline$\% 100$ & 19 & المجموع \\
\hline
\end{tabular}

شكل رقم (2) يوضح جاذبية الجر افيك لمحتوى البرنامج (برنامج أثنرقت)

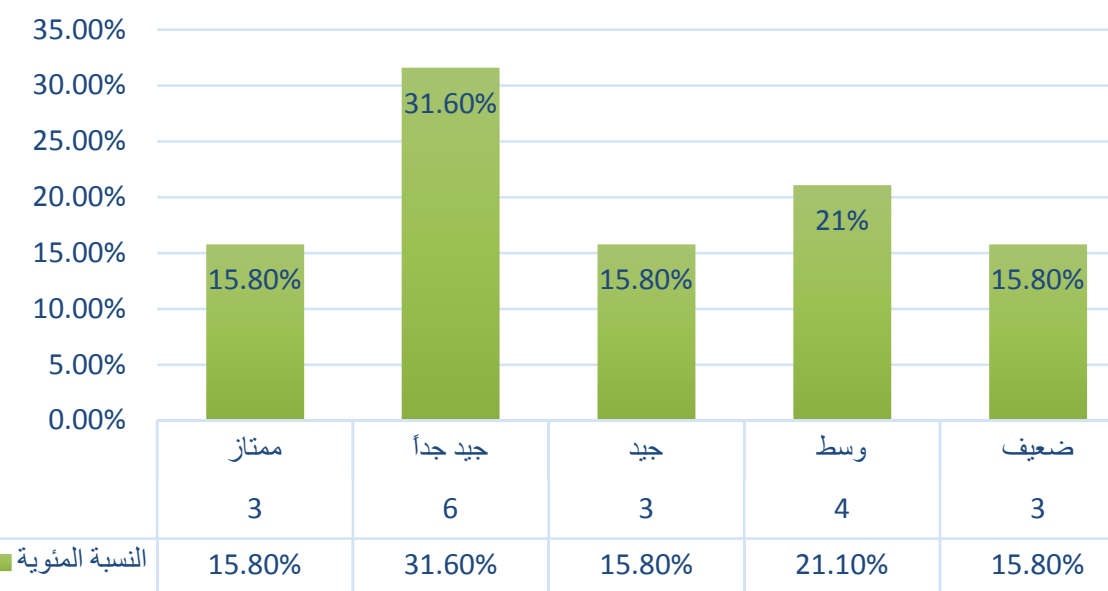

يلاحظ من الجدول و الثكل أعلاه أن جاذبية الجر افيك لمحتوى البرنامج جيدة جداً بنسبة بلغت 31.6\% من إجمالي المبحوثين، بينما بلغت نسبة جاذبية الجر افيك لمحتوى البرنامج 15.8\% للمبحوثين الذين يرون أنها ممتازة، وبنفس النسبة 15.8\% للذين يرون أنها جيدة، وكذالك نفس نسبة 15.8\% للذين يرون 


\section{فاعلبة الوسائط الطَعرد دةَ في نَطوير الطونتاج التلفزيونيج}

أن جاذبية الجرافيك ضعيفة، يمكن القول أن الأشكال والرسوم والألوان المستخدمة في برنامج أثنرقت جاذبة لمحتوى البرنامج. جدول رقم (3) يوضح توظيف انتقالات الصوت داخل الحلقة (برنامج أثنرقت)

\begin{tabular}{|c|c|c|}
\hline النسبة المئوية & التكرار & الفئة \\
\hline$\% 21.1$ & 4 & ممتاز \\
\hline$\% 42$ & 8 & جيد \\
\hline$\% 21.1$ & 4 & وسط \\
\hline$\% 15.8$ & 3 & ضعيف \\
\hline$\% 100$ & 19 & المجموع \\
\hline
\end{tabular}

شكل رقم (3) يوضح نوظيف انتقالات الصوت داخل الحلقة (برنامج أثرقت)

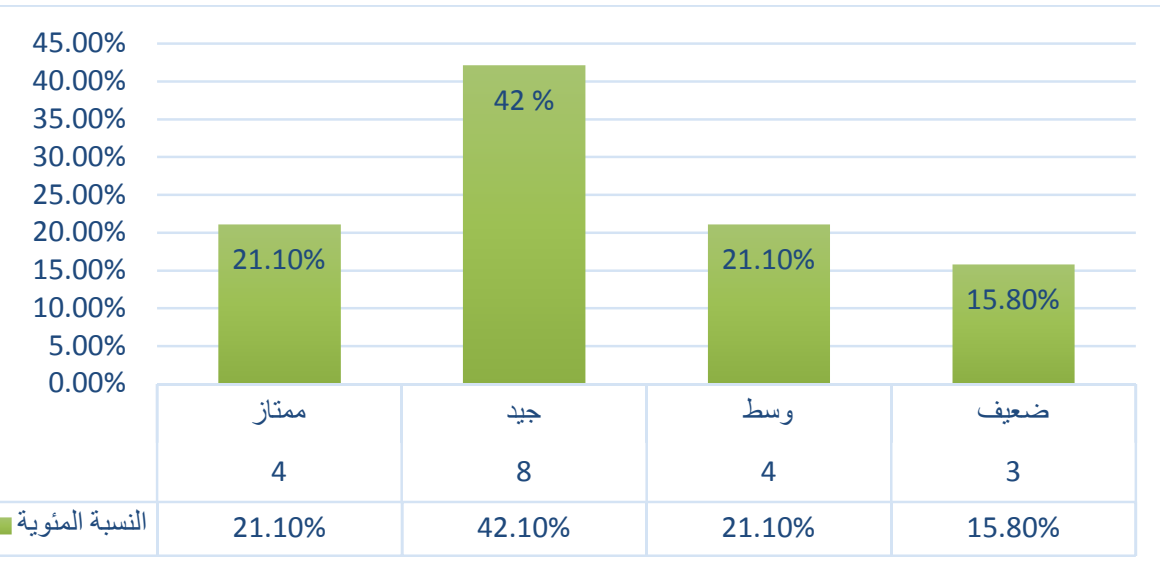

يلاحظ من الجدول و الثنكل أعلاه أن توظيف انتقالات الصوت داخــل

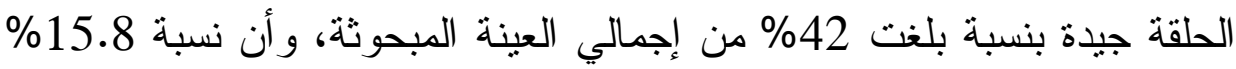
من أفر اد العينة المبحوثين يرون أن توظيف انتقالات الصوت ضعيفة، يثير ذلك الكاله

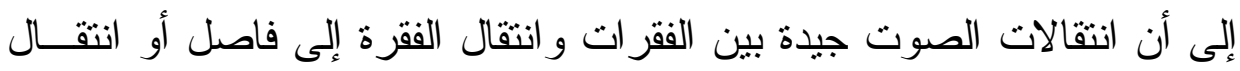

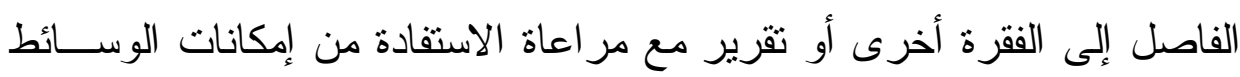


د. أسامة حسبع الرسول - أ. زينبه حاتم أحد كرار

\begin{tabular}{|c|c|c|}
\hline النسبة المئوية & التكرار & الفئة \\
\hline$\% 10.5$ & 2 & متتاز \\
\hline$\% 26.3$ & 5 & جيد جداً \\
\hline$\% 21.1$ & 4 & جيد \\
\hline$\% 15.8$ & 3 & وسط \\
\hline$\% 26.3$ & 5 & ضعيف \\
\hline$\% 100$ & 19 & المجموع \\
\hline
\end{tabular}

شكل رقم (4) يوضح فاعلية تصحيح الألوان على الفيديو (برنامج أثنرقت)

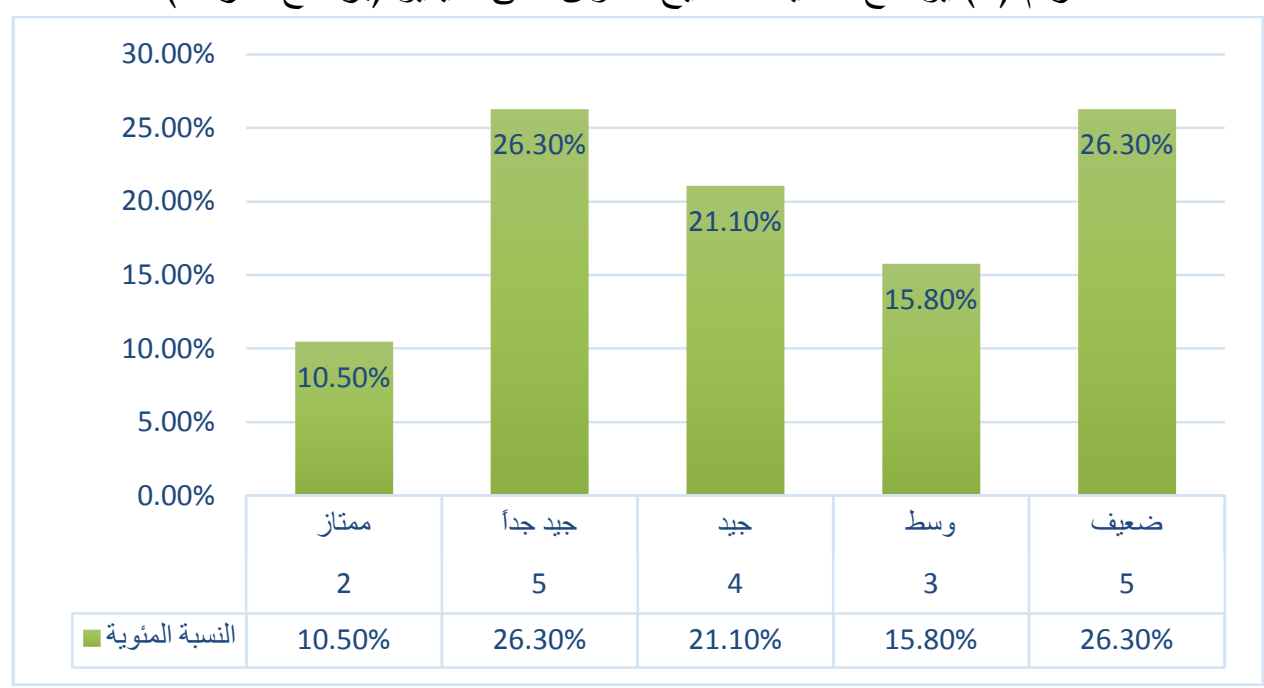

من الجدول و الثكل أعلاه يتبين التساوي في الفئات من حيث التكــرارات و النسب، حيث نجد أن نسبة 26.3\% من إجمالي أفر اد العينة المبحوثة يرون أن

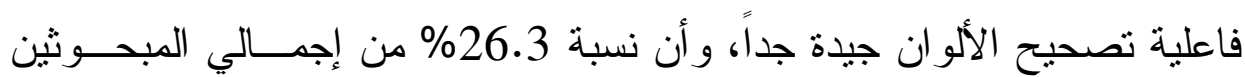
يرون أن الفاعلية ضعيفة، بينما نجد أن فاعلية تصحيح الألوان ممتــازة بنســبة 10.5 من إجمالي أفر اد العينة المبحوثين، يثير ذلك لأهمية تصحيح الألوان

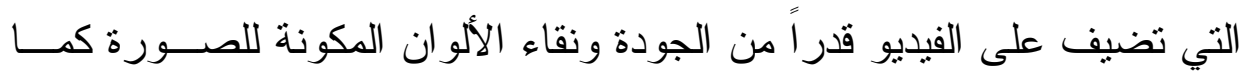




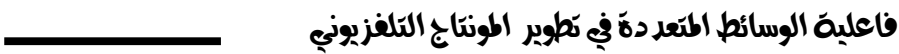

يعمل تصحيح الألوان على معالجة مشاكل الإضاءة أو انخفاض قيمة لون عـن الآخر من الألوان الأساسية.

جدول رقم (5) يوضح أسلوب المونتاج العام مع محتوى البرنامج (برنامج أثنرقت)

\begin{tabular}{|c|c|c|}
\hline النسبة المئوية & التكرار & الفئة \\
\hline$\% 15.8$ & 3 & متتاز \\
\hline$\% 42.1$ & 8 & جيد جداً \\
\hline$\% 26.3$ & 5 & جيد \\
\hline$\% 10.5$ & 2 & وسط \\
\hline$\% 5.3$ & 1 & ضعيف \\
\hline$\% 100$ & 19 & المجموع \\
\hline
\end{tabular}

شكل رقم (5) يوضح أسلوب المونتاج العام مع محتوى البرنامج (برنامج أثنرقت)

$45.00 \%$

$40.00 \%$

$35.00 \%$

$30.00 \%$

$25.00 \%$

$20.00 \%$

$15.00 \%$

$10.00 \%$

$5.00 \%$

$0.00 \%$

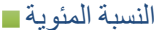

$15.80 \%$

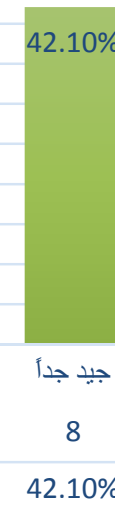

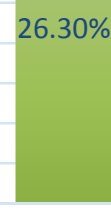

جيب

5

\section{$10.50 \%$}

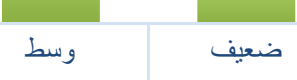

$26.30 \%$

$10.50 \%$

\section{1}

$5.30 \%$

يتضح من الجدول و الثكل أعلاه أن أسلوب المونتاج العام مـــع محتــوى البرنامج جيد جداً بنسبة 42.1\% من إجمالي العينة المبحوثة، بينما يرى 5.3 و

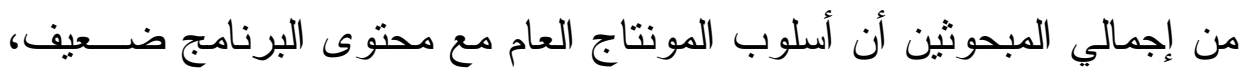

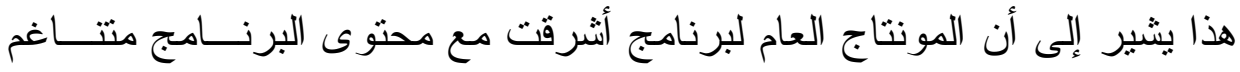

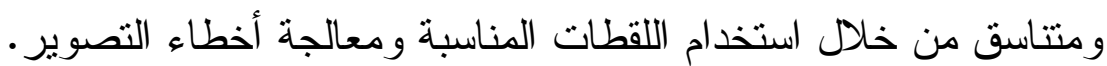


د. أساهة حسب الرسول - أ. زينبه حاتم أحد كرار

\begin{tabular}{|c|c|c|}
\hline النسبة المئوية & التكرار & الفئة \\
\hline$\% 78.9$ & 15 & متتاز \\
\hline$\% 15.8$ & 3 & جيد جداً \\
\hline$\% 5.3$ & 1 & جيد \\
\hline$\% 100$ & 19 & المجموع \\
\hline
\end{tabular}

شكل رقم (6) يوضح جاذبية ألو ان الجر افيك و الصور (برنامج التفاح الأخضر )

$90.00 \%$

$80.00 \%$

$70.00 \%$

$60.00 \%$

$50.00 \%$

$40.00 \%$

$30.00 \%$

$20.00 \%$

$10.00 \%$

$0.00 \%$
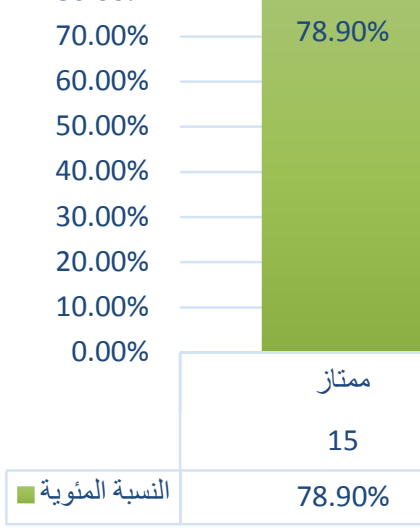

\begin{tabular}{|c|} 
جيد جداً $15.80 \%$ \\
3 \\
\hline $15.80 \%$
\end{tabular}

$5.30 \%$

جيد

1

$5.30 \%$

يتبين من الجدول والثكل أعلاه أن جاذبية ألوان الجرافيك و الصور ممتازة بنسبة 78.9\% من إجمالي المبحوثين، و أن نسبة 5.3\% من إجمالي أفر اد العينة المبحوثة يرون أن جاذبية الجر افيك جيدة، يشير ذلك إلى أن الجر افيك بنوعيه ثنائي الأبعاد وثلاثي الأبعاد يتم تصميمه وتلوينه بطريقة جاذبة لفكرة ومحتوى ليرى إنه

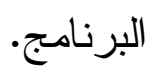

جدول رقم (7) يوضح جاذبية الجر افيك لمحتوى البرنامج (برنامج التفاح الأخضر )

\begin{tabular}{|c|c|c|}
\hline النسبة المئوية & التكرار & الفئة \\
\hline$\% 78.9$ & 15 & ممتاز \\
\hline$\% 10.5$ & 2 & جيد جداً \\
\hline
\end{tabular}




\begin{tabular}{|c|c|c|}
\hline$\% 5.3$ & 1 & جيد \\
\hline$\% 5.3$ & 1 & وسط \\
\hline$\% 100$ & 19 & المجموع \\
\hline
\end{tabular}

شكل رقم (7) يوضح جاذبية الجر افيك لمحتوى البرنامج (برنامج التفاح الأخضر )

\begin{tabular}{|c|c|c|c|c|}
\hline \multirow{3}{*}{$\begin{array}{r}100.00 \% \\
80.00 \% \\
60.00 \% \\
40.00 \% \\
20.00 \% \\
0.00 \%\end{array}$} & \multicolumn{4}{|l|}{$78.90 \%$} \\
\hline & متاز & جيد جدأ & جيد & وسط \\
\hline & 15 & 2 & 1 & 1 \\
\hline النسبة المئوية ـ & $78.90 \%$ & $10.50 \%$ & $5.30 \%$ & $5.30 \%$ \\
\hline
\end{tabular}

من الجدول و الثكل أعلاه يتبين أن جاذبية الجر افيك لمحتوى البرنــامج ممتاز بنسبة 78.9\% من إجمالي المبحوثين، وأن نسبة 10.5\% من إجمـالي

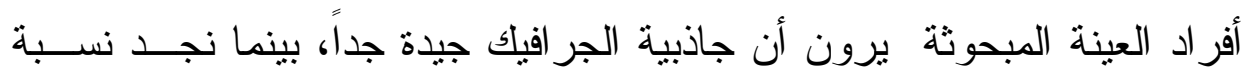
5.3 من إجمالي المبحوثين يرون أن جاذبية الجر افيك جيدة، وبنفس النســبة

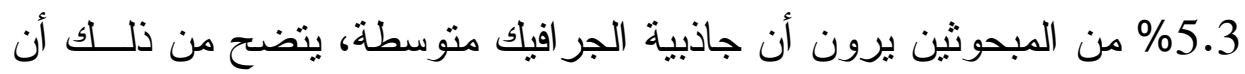
جاذبية الجر افيك تكمن في دقة و احتر افية و استخدام النوع المناسب من الحركــة مع الثكل أو الرسم بعبر عن اسم البرنامج أو محتوى البرنامج. جدول رقم (8) يوضح توظيف انتقالات الصوت داخل الحلقة (برنامج التفاح الأخضر )

\begin{tabular}{|c|c|c|}
\hline النسبة المئوية & التكرار & الفئة \\
\hline$\% 63.1$ & 12 & متاز \\
\hline$\% 31.6$ & 6 & جيد جداً \\
\hline$\% 5.3$ & 1 & جيد \\
\hline$\% 100$ & 19 & الججموع \\
\hline
\end{tabular}


د. أسامة حسب الرسول - أ. زينبه حاتم أحر كرار

شكل رقم (8) يوضح توظيف انتقالات الصوت داخل الحلقة(برنامج التفاح الأخضر )

$70.00 \%$

$60.00 \%$

$50.00 \%$

$40.00 \%$

$30.00 \%$

$20.00 \%$

$10.00 \%$

$0.00 \%$

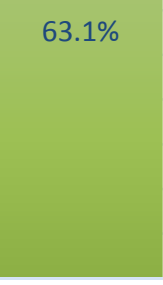

مثتاز

12

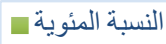

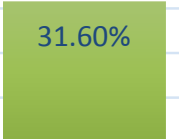

جيد جدأ

6

$31.60 \%$
$5.30 \%$

جبي

1

$5.30 \%$

من الجدول و الثكل أعلاه يلاحظ أن توظيف انتقالات الصوت داخــل

الحلقة ممتاز بنسبة 63.1\% من إجمالي المبحوثين، و أن نسـبة 31.6\% مــن

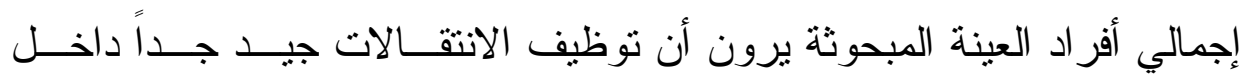
البرنامج، بينما برى 5.3\% من المبحوثين أن توظيف الانتقالات جيد، يشير ذلك إلى أن انتقالات الصوت ممتازة وتساعد على جذب انتباه المشاهد دون تشويش وبطريقة مريحة للأذن.

\begin{tabular}{|c|c|c|}
\hline النسبة المئوية & التكرار & الفئة \\
\hline$\% 78.9$ & 15 & متحتاز \\
\hline$\% 15.8$ & 3 & جيد جداً \\
\hline$\% 5.3$ & 1 & جيد \\
\hline$\% 100$ & 19 & المجموع \\
\hline
\end{tabular}




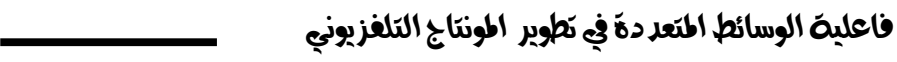

شكل رقم (9) يوضح فاعلية تصحيح الألوان على الفيديو (برنامج التفاح الأخضر)

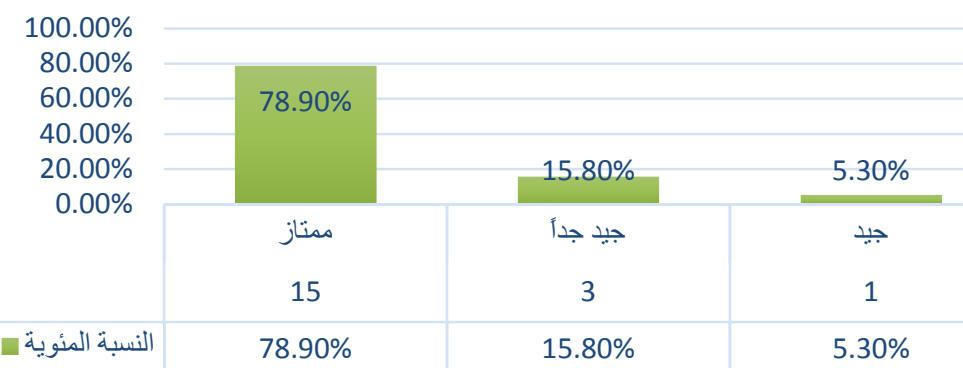

من الجدول و الثكل أعلاه يتبين أن فاعلية تصحيح الألوان على الفيديو

ممتازة بنسبة 78.9\% من إجمالي المبحوثين، بينما نجد أن نسبة 15.8\% من أفر اد العينة المبحوثة يرون أن فاعلية تصحيح الألوان جيدة جداً، ويرى 5.3\% من المبحوثين أن فاعلية تصحيح الألوان على الفيديو جيدة، يثير ذلك إلى أن تصحيح الألوان بحقق القيمة التي تضيف للفيديو قدراً من الجودة ونقاء الألوان المكونة للصورة كما يعمل تصحيح الألوان على معالجة مشاكل الإضاءة أو لأولي انخفاض قيمة لون عن الآخر من الألوان الأساسية. جدول رقم (10) يوضح أسلوب المونتاج العام مع محتوى البرنامج (برنامج التفاح الأخضر)

\begin{tabular}{|c|c|c|}
\hline النسبة المئوية & التكرار & الفئة \\
\hline$\% 73.6$ & 14 & متاز \\
\hline$\% 21.1$ & 4 & جيد جداً \\
\hline$\% 5.3$ & 1 & جيد \\
\hline$\% 100$ & 19 & المجموع \\
\hline
\end{tabular}


د. أسامة حسب الرسوه - أ. زبنبه حاتم أحر كرار

شكل رقم (10) يوضح أسلوب المونتاج العام مع محتوى البرنامج (برنامج التفاح الأخضر )

\begin{tabular}{|c|c|c|c|}
\hline $80.00 \%$ & & & \\
\hline $\begin{array}{l}70.00 \% \\
60.00 \%\end{array}$ & $73.70 \%$ & & \\
\hline $\begin{array}{l}60.00 \% \\
50.00 \%\end{array}$ & & & \\
\hline $\begin{array}{l}50.00 \% \\
40.00 \%\end{array}$ & & & \\
\hline $30.00 \%$ & & & \\
\hline $20.00 \%$ & & & \\
\hline $10.00 \%$ & & $21.10 \%$ & $5.30 \%$ \\
\hline $0.00 \%$ & & & \\
\hline & ممتاز & جيد جدأ & جيد \\
\hline & 14 & 4 & 1 \\
\hline النسبة المئوية & $73.70 \%$ & $21.10 \%$ & $5.30 \%$ \\
\hline
\end{tabular}

من الجدول والثكل أعلاه يلاحظ أن أسلوب المونتاج العام مع محتوى البرنامج ممتاز بنسبة 73.6\% من إجمالي المبحوثين، بينما نجد أن نسبة 21.1 من أفر اد العينة المبحوثة يرون أن أسلوب المونتاج العام جيد جداً، ويرى 5.3\% من المبحوثين أن أسلوب المونتاج العام مع محتوى البرنامج جيد، يثير ذلك إلى أن المونتاج العام مع محتوى البرنامج يتحقق باستخدام اللقطات المناسبة ومعالجة أخطاء التصوير و الأخطاء الصوتية و الفنية وتصحيح الألوان ونزكيب بداية البرنامج مع الفقر ات ثم الفو اصل ثم نهاية البرنامج.

النتائج:

\section{توصل البحث إلى عدة نتائج واستثتاجات أهمها:}

1- أثنبت البحث أنّ الجر افيك الجيد بنوعيه ثنائي الأبعاد وثثلاتـي الأبعـاد جــاذب إنب للمحتوى.

2- أثنبت البحث أن المونتاج العام للفيديو المتمنل في تنكـوين اللقطــات وزوراياهـــا

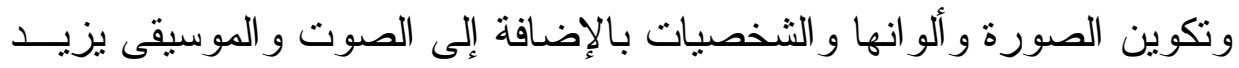
من جودة الفيديو • 


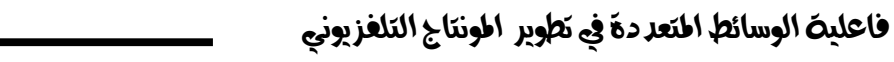

3- أكد البحث أن تحقيق الانسجام بين عناصر الوسائط المتعددة التي تظهر فـي

الكادر مع الثكل العام للصورة خاصة الديكور و الملابس مهم جداً للرفع مــن

مستوى جودة البر امج.

4- أكد البحث أن تصحيح الألوان يحقق القيمة التي تضيف للفيـديو قـدراً مــن

الجودة ونقاء الألو ان المكونة للصورة وذللك فـي برنــامج أثـــرقت بنســبة

26.3 وفي برنامج التفاح الأخضر بنسبة 78.9\%.

التوصيات:

توصل البحث إلى التوصيات التالية:

1. التوظيف الجيد للصورة و استخدام التقنيات الحديثة للمؤثز ات البصرية.

2. الاهتمام بعنصر الجر افيكس باعتباره أهم عنصر من عناصــر الوســائط

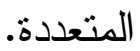

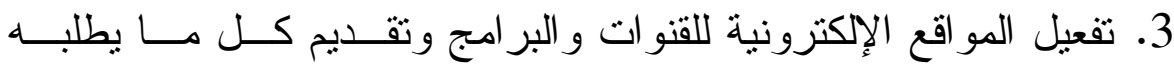

المشاهد.

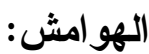

1- المسلمي، إبر اهيم : (1999م)مناهج البحث في الار اسات الإعلامية، ط1،

القاهرة، دار الفكر العربي ص 17.

2- إسماعيل، محمود حسن : (2011م) مناهج البحث الإعلامي، ط1، دار الفكر

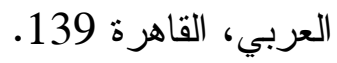

3- إسماعيل، محمود حسن : مرجع سابق ص 140.

4- بصبوص و أخرون (2004م) الوسائط المتعددة تصميم وتطبيقات، ط1،

عمان، دار اليازوري العلية للنشر و التوزيع ص10. 
د. أسامة حسبع الرسول - أ. زينبه حاتم أحد كرار

5- عمر، أحمد مختار (2008م) معجم اللغة العربية المعاصرة، ط1، القاهرة،

$$
\text { عالم الكتاب ص } 142 .
$$

6- شلبي، كرم (1988م) معجم المصطلحات الإعلامية، الطبعة الأولي، دار

$$
\text { الشروق، القاهرة. ص } 166 .
$$

7- عمر ، أحمد مختار مرجع سابق ص 145

8- الغمراوي، رجاء عبد الرازق : (2013م) قواعد الإخراج بين النظرية

و التطبيق، ط1، الإسكندرية، دار المعرفة الجامعية، ص 175.

9- إين منظور ، محمد بن جلال الدين (2000م)لسان العرب، المجلد الأول، دار

صادر للطباعة و النشر ، لبنان، ص 9.

10- محدين، عثمان عوض الكريم محمدين (2005م) تخطيط البرامج التلفزيونية،

ط1، الخرطوم، فهرسة المكتبة الوطنية، ص 20.

11- الثيخ، أم هاني أبوصباح (2007م) فاعلية الوسائط المتعددة في إنتاج برامج

التلفزيون، جامعة السودان للعلوم و التكنولوجيا، رسالة دكتور اه، غير منشورة، ص

12- الجيلاني، الأرقم (2012م) فاعلية الصوت و الصورة في المنتج التلفزيوني،

جامعة السودان للعلوم و التكنولوجيا، رسالة دكتور اه، غير منشورة، ص 13.

13- حسن، عباس ناجي (2016م) الوسائط المتعددة في الإعلام الإكتروني، ط1،

عمان، دار صفاء للنشر و التوزيع، ص 132.

14- سليم، حنان أحمد (2015م) فنون الفيديو الرقمي، ط1، الرياض، مكتبة

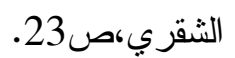

15- شعلان، محمد إبر اهيم (2017م) تصميم و إنتاج الوسائط المتعددة بإستخدام

Flash MX، ط1، دار الكتاب الحديث،ص 39.

16- محطات تقنية، 2018م 


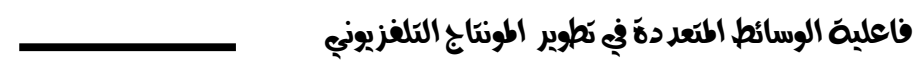

17- حسن، عباس ناجي، مرجع سابق، ص 132.

18- ت تكنولوجيا وسائط متعددة 2018م

19- حسن، عباس ناجي، مرجع سابق ص 134.

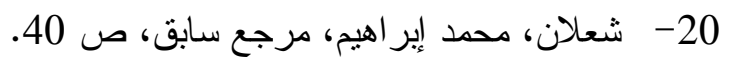

21- - تكنولوجيا الوسائط المتعددة 2018م

22- حسن، عباس ناجي، مرجع سابق، ص 135.

23- تكنولوجيا الوسائط المتعددة 2018م

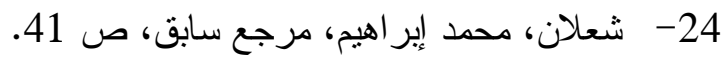

25- حسن، عباس ناجي، مرجع سابق، ص 137.

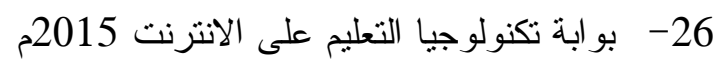

27- شلتوت، محمد شوفي عبد الفتاح (2016م) الإنفوجرافيك من التخطيط إلى الثى

الإتتاج، ط1، الرياض، مكتبة الملك فهز الوطنية للنشر، ص 145.

28- شلتوت، محمد شوقي عبد الفتاح، المرجع السابق، ص 110

$29-29$

30- برهوم (2016)، ص 14-15.

31- الغمر اوي، رجاء عبد الر ازق، مرجع سابق، ص 175.

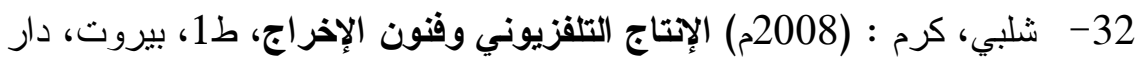

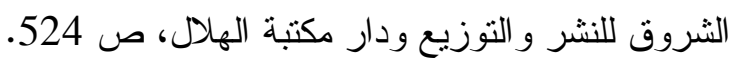

$$
\begin{aligned}
& \text { 33- شلبي، كرم، المرجع السابق،ص } 525 . \\
& \text { 34- شلبي، كرم، المرجع السابق، ص } 27 . \\
& \text { 35- شلبي، كرم، المرجع السابق، ص } 128 .
\end{aligned}
$$

36- إبر اهيم و آخرون (2015م) إنتاج البرامج الإذاعية و التلفزيونية، ط1، القاهرة

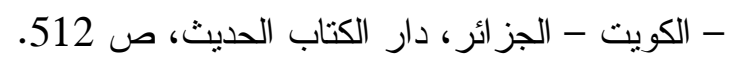


د. أسامة حسب الرسول - أ. زينبه حاتم أحد كرار

$$
\begin{aligned}
& \text { 37- شلبي، كرم، مرجع سابق، ص } 135 . \\
& \text { 38- إير اهيم و آخرون، مرجع سابقئ } \\
& \text { 39- شلبي، كرم، مرجع سابق، ص } 135 . \\
& \text { 40- إير اهيم و أخرونا، مرجع سابق513. } \\
& \text { 41- ش شبي، كرم، مرجع سابق، ص } 139 . \\
& \text { 42- شلبي، كرم، مرجع سابق، ص } 273 . \\
& \text { 43- محمد، 2018م } \\
& \text { 44- ويكيبيديا 2018م } \\
& \text {.2018،MBC.net }-45 \\
& \text {.2018،MBC.net }-46 \\
& \text { 2018،YouTube }-47 \\
& .2018 \text { ،MBC Group -48 } \\
& \text { المصادر و المر اجع: } \\
& \text { أولاً : المعاجم: }
\end{aligned}
$$

1- ابن منظور ، محمد بن جال الدين (2000م) لسان العرب، المجلد

$$
\text { الأول، دار صادر للطباعة و النشر، لبنان. }
$$

2- عمر ، أحمد مختار (2008م) معجم اللغة العربية المعاصرة، ط1، ول،

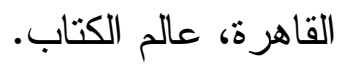

3-شلبي، كرم (1988م) معجم المصطلحات الإعلامية، الطبعة الأولي، دار

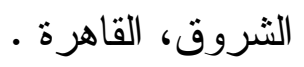




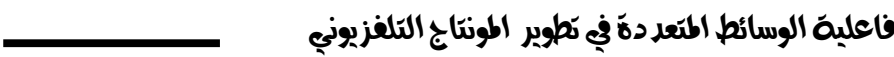

ثانياً : الرسائل الجامعية:

4- الجيلاني، الأرقم (2012م) فاعلية الصوت و الصورة في المنتج

التلفزيوني، جامعة السودان للعلوم و التكنولوجيا، رسالة دكتور اه، غير

$$
\text { منشورة. }
$$

5- الثيخ، أم هاني أبوصباح (2007م) فاعلية الوسائط المتعددة في إنتاج برامج التلفزيون، جامعة السودان للعلوم و التكنولوجيا، رسالة دكتور اه،

$$
\text { غير منشورة. }
$$

6- عوض الكريم، ياسر يوسف (2007م) دور تكنولوجيا الاتصال في إنتاج البرامج التتلزيونية، جامعة أم درمان الإسلامية، رسالة دكتور اه،

$$
\text { غير منشورة. }
$$

ثالثاً: المراجع العربية:

7- الغمر اوي، رجاء عبد الرازق : (2003م) قواعد الإخراج بين النظرية

والتطبيق، ط1، الإسكندرية، دار المعرفة الجامعية.

8- المسلمي، إبر اهيم : (1999م)مناهج البحث في الدراسات الإعلامية،

$$
\text { ط1، القاهرة، دار الفكر العربي. }
$$

9- إبر اهيم و آخرون (2015م) إنتاج البرامج الإذاعية و التلفزيونية، ط1،

$$
\text { القاهرة - الكويت - الجزائر، دار الكتاب الحديث. }
$$

10- إسماعيل، محمود حسن : (2011م) مناهج البحث الإعلامي، ط1،

$$
\text { دار الفكر العربي، القاهرة. }
$$

11- بصبوص و أخرون (2004م) الوسائط المتعددة تصميم وتطبيقات،

ط1، عمان، دار اليازوري العلمية للنشر و التوزيع.

12- حسن، عباس ناجي (2016) الوسائط المتعددة في الإعلام

الإكتروني، ط1، عمان، دار صفاء للنشر والتوزيع. 
د. أسامة حسب الرسول - أ. زينبه حاتم أحد كرار

13- سليم، حنان أحمد (2015م) فنون الفيديو الرقمي، ط1، الرياض،

مكتبة الثقري.

14- شعلان، محمد إبراهيم (2017م) تصميم وإنتاج الوسائط المتعددة

بإستخدام Flash MX، ط1، دار الكتاب الحديث.

15- شلبي، كرم : (2008م) الإتتاج التلفزيوني وفنون الإخراج، ط1،

بيروت، دار الثروق للنشر و التوزيع ودار مكتبة الهال.

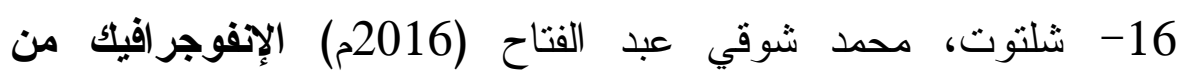

التخطيط إلى الإنتاج، ط1، الرياض، مكتبة الملك فهد الوطنية للنشر

17- محمدين، عثمان عوض الكريم محمدين (2005م) تخطيط البرامج

التلفزيونية، ط1، الخرطوم، فهرسة المكتبة الوطنية.

رابعاً : المجلات والأوراق العلمية

18- الناجد و آخرون (2016م) الهندسة والتكنولوجيا - الباحثون السوريون.

19- تكنولوجيا الوسائط المتعددة.

20

خامساً: مواقع الإنترنت

2018.،-MBC.net 21

.2018 - MBC Group22

.2018،- YouTube23 